\title{
Optimizing micropropagation conditions for a recalcitrant ninebark (Physocarpus opulifolius L. maxim.) cultivar
}

\author{
K. Jagiełło-Kubiec ${ }^{1} \cdot$ K. Nowakowska ${ }^{1}$ (D) - A. Ilczuk ${ }^{1} \cdot$ A. J. Łukaszewska ${ }^{1}$
}

Received: 17 June 2020 / Accepted: 28 December 2020/Published online: 3 February 2021 / Editor: Yong Eui Choi

(C) The Author(s) 2021

\begin{abstract}
Ninebark is a very popular ornamental shrub. Micropropagation is an efficient method for mass production of uniform plant material. This study was designed to develop and optimize conditions at all phases of ninebark micropropagation. For the multiplication stage, the Murashige and Skoog (MS) medium at full concentration and pH 5.8 was chosen as the basal medium. Sorbitol proved a more effective carbohydrate source than fructose, with no adverse effects on shoot vitrification or the medium itself. The best shoot production, both in number and length, was on the medium enriched with 2 and $3 \mathrm{mg} \cdot \mathrm{L}^{-1} \mathrm{zeatin}$. High numbers of shoots were also obtained in treatments with $1 \mathrm{mg} \cdot \mathrm{L}^{-1}$ 6-benzyladenine (BA) or $2 \mathrm{mg} \cdot \mathrm{L}^{-1}$ meta-Topolin (mT) in the basal medium. BA was the most cost-effective cytokinin. There was a positive effect of the gibberellic acid on proliferation: the highest shoot number per explant was produced in the presence of $1 \mathrm{mg} \cdot \mathrm{L}^{-1} \mathrm{GA}_{3}$. No effect of the culture age (up to 20 subcultures) on the percentage of regenerating explants was evident, and the highest numbers of shoots were obtained between passages 10 and 17. For rooting, the MS medium at half strength was used. The best rooting was at $1 \mathrm{mg} \cdot \mathrm{L}^{-1} \mathrm{IBA}$. Spraying the in vitro rooted cuttings with abscisic acid (ABA) favored plant acclimation to the ex vitro conditions. Ex vitro rooting, including the treatments with IBA and ABA, shortened the production time by approximately one third.
\end{abstract}

Keywords Auxin $\cdot$ Cytokinin $\cdot$ Carbohydrate source $\cdot$ In vitro $\cdot$ Plant growth regulators

\section{Introduction}

Ornamental shrubs, also used in reforestation programs and soil retention systems, are in high demand in private and urban green areas. To meet the growing demand the nurserymen seek new and more efficient propagation. As a rule, conventional propagation techniques are not sufficiently effective in propagation of woody plants and require large quantities of stock plants.

Ninebark has become incredibly famous recently. Its several cultivars are hardy, colorful, and well-growing in full sun or semi-sunshine tolerating a wide range of soil types. Because the leaves are insensitive to air pollution, it is also used for phytoremediation (Popek et al. 2018). However, there are general problems in conventional propagation of

K. Nowakowska

karolina_nowakowska@sggw.edu.pl

1 Section of Ornamental Plants, Institute of Horticultural Sciences, Warsaw University of Life Sciences (SGGW), 166

Nowoursynowska str, 02-787 Warszawa, Poland ninebark as the rooting rate of stem cuttings differs among the cultivars (50-85\%), at times falling below the economic threshold, i.e., 50\% (Pacholczak and Szydło 2008). Without a rooting stimulator, the cultivar used here rooted only in $26 \%$ when propagated by semi-lignified cuttings (Pacholczak 2015). Thus the in vitro micropropagation appears as an effective alternative to the standard propagation by cuttings asaccording to literature - it is capable for producing large quantities of the true-to-type plant material (Hussain et al. 2012). The latter aspect is crucial in cultivar propagation as they do not breed true when propagated by seeds.

The in vitro shoot multiplication and rooting are affected by several factors (Haque et al. 2003), one of which is the concentration and type of the exogenous carbon sources in the medium as an energy source and the osmotic potential regulator (De Neto and Otoni 2003). A continuous supply of carbohydrates from the medium is necessary for plants cultured in vitro, because under low light intensity, limited gas exchange and high relative humidity in growth chambers, the photosynthetic activity is greatly reduced (Kozai 1991). Earlier trials on ninebark identified fructose as the best carbon source for multiplication and rooting of the cultivar DIABLE D'OR 'Mindia' (Ilczuk et al. 2013). However, vitrification of 
new axillary shoots produced on the MS medium supplemented with fructose was frequent, and issues with media solidification were frequent (unpublished data). In this study, fructose was compared with another carbohydrate, sorbitol. Sorbitol is said to be a suitable carbon source for plants of Rosacae family where ninebark belongs (Moing et al. 1992; Ahmad et al. 2007; Yaseen et al. 2013). Perhaps positive effects of sorbitol can be attributed to the fact that it is the main photosynthesis product in this family (Moing et al. 1992).

Nutrient composition of a culture medium is critical for the initial explant response (Hussain et al. 2012), and different media with different formulations are in use. In 1962, Murashige and Skoog developed the nutrient composition (MS) with high amounts of potassium and nitrogen ions. Although originally developed for tobacco (Nicotiana), it has become the most popular medium for the tissue culture in a wide range of plants. On the other hand, the formulation of Nitsch and Nitsch in 1969 (NN) has less than half the amount of salts as compared with MS; in Schenk and Hildebrandt's (1972) medium developed for suspension cultures, a high proportion of potassium nitrate is present. The medium of Quoirin an Lepoivre (1977) formulated for propagation of Prunus, contains one fourth of $\mathrm{NH}_{4} \mathrm{NO}_{3}$ present in the MS and is supplemented with $\mathrm{Ca}\left(\mathrm{NO}_{3}\right)_{2}$. For Rubus, Anderson (1980) developed the medium containing one fourth of the amounts of $\mathrm{NH}_{4} \mathrm{NO}_{3}$ and $\mathrm{KNO}_{3}$ present in MS but also containing $\mathrm{NaH}_{2} \mathrm{PO}_{4} \cdot \mathrm{H}_{2} \mathrm{O}$. In 1980 Lloyd and McCown prepared a medium for micropropagation of woody plants (WPM), more diluted than MS.

Plant growth regulators (PGRs) affect cell divisions and their differentiation as well as further plant growth. Therefore, their presence in a culture medium is crucial. The type and concentration of a PGR depends on the plant species and the explant type as well as the experimental goal. Generally, high auxin concentrations favor root development, while high concentrations of cytokinins stimulate shoot regeneration (Perveen et al. 2011; Hussain et al. 2012).

Cytokinins are adenine derivatives capable of inducing cell divisions in tissue cultures, initiating shoots and stimulating their proliferation and further growth, both of which are critical for in vitro multiplication efficiency. Exogenously applied cytokinins are more active in the presence of an auxin (Perveen et al. 2011; Faisal et al. 2018; Nowakowska et al. 2019). Frequently used cytokinins are of natural origin such as zeatin (Zea), the 2-isopenthenyladenine (2iP), kinetin (Kin), and 6-benzyladenine (BA) or synthetic cytokinins such as thidiazuron (TDZ) (Pierik 1997). BA is the most commonly used cytokinin for micropropagation, but plant taxa differ in their preference towards specific cytokinins. Recently, metaTopolin (mT) has become a more common cytokinin in the in vitro plant production (Werbrouck et al. 1996; Gentile et al. 2014; Koszeghi et al. 2014). In certain species gibberellic acid $\left(\mathrm{GA}_{3}\right)$ may also induce the formation of axillary shoots
(George et al. 2007). GA 3 in combination with BA accelerated in vitro shoot multiplication in certain wild roses, thus increasing their micropropagation efficiency (Pawłowska 2011).

An important factor during plant micropropagation is the number of subcultures (passages). The effect of subculture on the multiplication rate varies from one species to another, optimization of the number of passages is a very important aspect of the entire protocol (Kumar et al. 2010). Repeated subculture cycles can reduce the plant regenerative capacity as in Gmelina arborea (Naik et al. 2003) or in fruit tree root stocks (Vujović et al. 2012). A drop in the multiplication rate in consecutive passages of shoots on medium with a constant hormonal composition was also observed in six species and cultivars of Rosaceae (Norton and Norton 1986). However, in Mahonia leschenaultia, repeated passages of shoot cultures through at least 10 cycles resulted in successful proliferation without a loss of vigor, growth, or morphological abnormalities (Radha et al. 2013). Hence, the effect of the long-term growth in the same culture medium (20 subcultures, i.e., over 3 years) was also an important aspect of this study.

Rooting of cuttings is a critical step in micropropagation of woody plants where adventitious root development is more difficult than in herbaceous species. Inability to induce adventitious roots may be a barrier to use in vitro cultures to propagate trees and shrubs (Yan et al. 2010; Shekhawat and Manokari 2016). The main plant growth regulator responsible for rooting is auxin. Auxin as such does not participate in the formation of root primordia but activates the already existing ones or induces the new ones (De Klerk et al. 1999). For rooting of microcuttings, the indole-3-butyric acid (IBA) is mostly used (Ďurkovič and Bukovská 2009; Feng et al. 2009), while 1-naphtalene-acetic acid (NAA) and indole-3acetic acid (IAA) are less frequently applied (Ďurkovič 2008; Duurkovič and Bukovská 2009; Hartmann et al. 2011).

When transferred to the ex vitro conditions, plants may be damaged by rapid changes in the environmental conditions. This calls for a period of acclimation as the final phase of micropropagation. Micropropagated plants are produced under high humidity; therefore, they often have poorly developed epicuticular waxes and the cuticle, their stomata function incorrectly so their photosynthesis rate is low (Hazarika 2006; Mišalová et al. 2009). As stomata do not close properly, the transpiration rate is high, and this may severely impact the survival rate of microcuttings when they are transferred to the ex vitro conditions (Ziv 1995). The process of acclimation can be accelerated by hardening plants in vitro or after planting them out in a greenhouse. The transpiration rate should be limited under such conditions, for example, by antitranspirants such as the abscisic acid (ABA) (Pospisilova et al. 1999). ABA increases plant tolerance to environmental stresses - hastens stomata closing thus limiting water losses (Rai et al. 2011). Light is another important environmental 
factor which should be manipulated during plant acclimation. An increase in its intensity stimulates growth of new leaves, and these are adapted from the start to a fully autotrophic function (Donnelly and Vidaver 1984).

As ever, economic factors play an important role in in vitro propagation. To save time, costs and labor the nurserymen tend to reduce a number of micropropagation stages (Shekhawat and Manokari 2015), by introduction ex vitro rooting of cuttings. Plants of Simmondsia chinensis were produced in 135 days when the cuttings were rooted ex vitro; in conventional in vitro rooting, 180 days were needed (Singh and Agarwal 2016). According to many authors, the ex vitro rooting increases plant survivability during acclimation and further growth in greenhouse as compared with cuttings rooted in vitro, and the root system developed ex vitro is of better quality (Phulwaria and Shekhawat 2013; Shekhawat and Manokari 2015; Ravindran et al. 2016; Singh and Agarwal 2016).

Data on ninebark micropropagation is scarce. Because its cultivars vary in their responses to propagation conditions (Pacholczak and Szydło 2008; Pacholczak 2015), these should often be tailored individually to each one. With this in mind, tests were undertaken to develop an efficient method of micropropagation of for the ninebark cultivar "Dart's Gold," including shortening of the production cycle. Cv. "Dart's Gold" is a popular, hardy, and very decorative shrub not readily rooting when propagated by cuttings. Several factors known to be important in micropropagation were tested, such as different mineral compositions of the media, its concentration, $\mathrm{pH}$, as well as the effects of growth regulators in successive stages of ninebark micropropagation.

\section{Material and methods}

1. The experimental material and culture medium The experimental material for the experiments were the apical segments of shoots (at least $1.3 \mathrm{~cm}$ long) collected randomly from established 8-10 week old in vitro cultures of ninebark cv. "Dart's Gold" growing on the MS medium enriched with $1 \mathrm{mg} \cdot \mathrm{L}^{-1} \mathrm{BA}(4.44 \mu \mathrm{M})$ and $0.1 \mathrm{mg} \cdot \mathrm{L}^{-1} \mathrm{NAA}(0.54 \mu \mathrm{M})$.

The culture medium was prepared according to Murashige and Skoog (1962) except in experiment 2 where different media were compared. Sorbitol was used in concentration $30 \mathrm{~g} \cdot \mathrm{L}^{-1}$, except in experiment 1 , where two carbohydrates were compared. Media were solidified with $8.0 \mathrm{~g} \cdot \mathrm{L}^{-1}$ Bacto $^{\text {TM }}$ Agar (Sparks, Maryland), and their $\mathrm{pH}$ at 5.8 before autoclaving was adjusted with $1 \mathrm{~N} \mathrm{NaOH}$ and $1 \mathrm{~N} \mathrm{HCl}-$ except in experiment 3 where four $\mathrm{pH}$ levels were compared. Media were portioned into $450 \mathrm{ml}$ jars, $50 \mathrm{ml}$ in each and autoclaved for $20 \mathrm{~min}$ at $121^{\circ} \mathrm{C}$ and $110 \mathrm{kPa}$. There were 10 replicates (jars) each containing 5 explants, i.e., in total 50 explants per treatment. The jars with explants were placed in a phytotron under $23 \pm 1^{\circ} \mathrm{C} 16 \mathrm{~h}$ day with light of
$35 \mu \mathrm{mol} \cdot \mathrm{m}^{-2} \cdot \mathrm{s}^{-1}$ photosynthetic photon flux (PPF), provided by fluorescent lamps. The relative humidity was maintained as $55-65 \%$. After 8 weeks of culture, the percentage of regenerating explants, numbers of shoots per explant, and root lengths $(\mathrm{cm})$ were scored.

Multiplication To assess the effect of the carbon source on multiplication rates (experiment 1), the explants were placed on the MS medium with either fructose or sorbitol, in concentrations: $1,2,3,4$, or $5 \%$. The control treatment was the medium without sugar.

The effect of macronutrients on the multiplication rates (experiment 2) was assessed on the following culture media: AN (Anderson 1980), MS (Murashige and Skoog 1962), NN (Nitsch and Nitsch 1969), QL (Quoirin and Lepoivre 1977), SH (Schenk and Hildebrandt 1972), and WPM (Woody Plant Medium - Lloyd and McCown 1980). Vitamins and micronutrients were added according to the MS. All media were supplemented with $1 \mathrm{mg} \cdot \mathrm{L}^{-1} \mathrm{BA}$ and $0.1 \mathrm{mg} \cdot \mathrm{L}^{-1}$ NAA. The effect of macronutrient concentrations on the multiplication rates (experiment 3) was tested on four MS variants: $1 / 2 \mathrm{MS}$, MS, $1 \frac{1}{2} \mathrm{MS}$, and $2 \mathrm{MS}$. The effect of $\mathbf{p H}(\mathrm{ex}-$ periment 4) was tested on MS media at $\mathrm{pH} 5.4,5.8,6.2$, and 6.6 as measured before autoclaving.

The effect of a cytokinin and its concentration was evaluated in Experiment 5 where the MS medium was supplemented with $0.54 \mu \mathrm{M}$ NAA and the following cytokinins: 2iP, BA, kinetin, meta-Topolin, TDZ, and zeatin in the following concentrations: $0.5,1.0,2.0$, or $3.0 \mathrm{mg} \cdot \mathrm{L}^{-1}$. The control treatment was the MS medium without growth regulators. The effect of the gibberellic acid on shoot proliferation and elongation (experiment 6) was tested on MS supplemented with $0.1 \mathrm{mg} \cdot \mathrm{L}^{-1} \mathrm{NAA}(0.54 \mu \mathrm{M}), 1 \mathrm{mg} \cdot \mathrm{L}^{-1} \mathrm{BA}(4.44 \mu \mathrm{M})$ and $\mathrm{GA}_{3}$ in concentration: $0,0.25,0.5,1.0$ or $2.0 \mathrm{mg} \cdot \mathrm{L}^{-1}$. The MS medium without growth regulators served as control.

The effect of the culture age, i.e., passage number, on the multiplication ratio was tested throughout the duration of the entire experiment and included 20 successive passages (Experiment 7). Each passage started with explants placed on the MS medium supplemented with $0.1 \mathrm{mg} \cdot \mathrm{L}^{-1} \mathrm{NAA}$ and $1 \mathrm{mg} \cdot \mathrm{L}^{-1} \mathrm{BA}$. Plants were transferred to fresh medium after every 8 wk of culture. For each successive passage five shoots were taken from each jar (50 in total).

Rooting The material was collected from 8 to 10 week old in vitro cultures growing on MS supplemented with $1 \mathrm{mg} \cdot \mathrm{L}^{-1} \mathrm{BA}$ and $0.1 \mathrm{mg} \cdot \mathrm{L}^{-1} \mathrm{NAA}$. Apical parts of regenerated microshoots at least $1.5 \mathrm{~cm}$ long were placed onto the rooting medium (MS). After 8 weeks, the following parameters were scored: $\%$ of rooted cuttings, mean number of roots per cutting, and mean root length. Each treatment contained 10 replications with 5 plants in each (50 cuttings in total). 
To test the effect of macronutrient concentration in the rooting medium (Experiment 8), the explants were placed onto the medium containing $1 \mathrm{mg} \cdot \mathrm{L}^{-1}(4.92 \mu \mathrm{M}) \mathrm{IBA}$ and different concentrations of the MS macronutrients (Table 1). The other media components were as in the original MS formulation.

To test the effects of the type and concentration of auxin (Experiment 9), cuttings were placed onto a one-half concentration MS with auxins IBA or NAA in concentrations: 0.1, $0.5,1.0,2.0$, and $3.0 \mathrm{mg} \cdot \mathrm{L}^{-1}$, while the control MS medium did not contain auxins.

Acclimation The material for test of acclimation came from 8 to 10 week cultures on one half MS with $4.92 \mu \mathrm{M}$ IBA (experiment 10). Plants were at least $3.5 \mathrm{~cm}$ tall with 9 internodes and 4-6 roots not shorter than $1 \mathrm{~cm}$ each. Plants were removed from the jars, and their roots were rinsed with distilled water to remove the culture medium and potted into $\mathrm{M} 9$ pots $(9 \mathrm{~cm}$ in diameter) with sterile mixture of white peat and perlite (1:2 v/ v). The pots were placed in transparent containers (Curver 33 1) and treated with fungicides $(0.15 \%$ Topsin $\mathrm{SC}+0.2 \%$ Captan). The containers were closed with transparent covers to maintain stable humidity and placed in a greenhouse at 25/ $20^{\circ} \mathrm{C}$ (day/night) and RH 50\%. After 1 week the covers were gradually removed to allow plants to acclimatize to the ex vitro conditions. Eight weeks after potting the percentage of acclimatized plants was scored, their height measured and internode number counted. Each treatment contained 5 replicates with 10 plants each (50 plants in total).

To improve the acclimation, plants were sprayed with ABA: $0.5,1$, or $2 \mathrm{mg} \cdot \mathrm{L}^{-1}(1.89,3.78$ or $7.57 \mu \mathrm{M}$ ) (experiment 11). The effect of the treatment was assessed after 8 wk under greenhouse conditions. The effect of ABA was also tested in combination with supplementary lightning (experiment 12). Tested plants were transferred to the greenhouse and sprayed with $1 \mathrm{mg} \cdot \mathrm{L}^{-1} \mathrm{ABA}$ or water, and for the following 8 weeks, one half of the plants were illuminated between 2 and 9 p.m. with sodium lamps with light intensity of $230 \mu \mathrm{mol} \cdot \mathrm{m}^{-2} \cdot \mathrm{s}^{-1}$ (measured with Radiometer-Photometer RF-100 Sanopan). The other half of plants were grown without supplementary lightning.

Table 1 Macronutrient composition of the MS media used in different concentrations

\begin{tabular}{llll}
\hline \multirow{2}{*}{ Macronutrients $\left(\mathrm{mg} \cdot \mathrm{L}^{-1}\right)$} & \multicolumn{2}{l}{ Media } & \\
\cline { 2 - 4 } & $1 / 4 \mathrm{MS}$ & $1 / 2 \mathrm{MS}$ & MS \\
\hline $\mathrm{NH}_{4} \mathrm{NO}_{3}$ & 412.5 & 825.0 & 1650.0 \\
$\mathrm{KNO}_{3}$ & 475.0 & 950.0 & 1900.0 \\
$\mathrm{CaCl}_{2}$ & 83.0 & 166.0 & 332.0 \\
$\mathrm{MgSO}_{4}$ & 45.1 & 90.3 & 180.5 \\
$\mathrm{KH}_{2} \mathrm{PO}_{4}$ & 42.5 & 85.0 & 170.0 \\
\hline
\end{tabular}

Ex vitro rooting A test was undertaken to combine simultaneous rooting and acclimation to the ex vitro conditions (Experiment 13). The cuttings were taken out of the jars, cut to $2.5 \mathrm{~cm}$ in length and soaked for $15 \mathrm{~min}$ either in distilled water (control treatment) or in water solutions of 1 or $2 \mathrm{mg} \cdot \mathrm{L}^{-1}$ IBA (Table 2), and planted into Styrofoam boxes filled with the mixture of white peat and perlite $(v / \mathrm{v} 2: 1)$. The cuttings were then sprayed with distilled water or the solution of $1 \mathrm{mg} \cdot \mathrm{L}^{-1} \mathrm{ABA}$. To protect against pathogens, the cuttings were treated with the fungicide mixture: $0.15 \%$ Topsin SC plus $0.2 \%$ Captan. The boxes were placed in the greenhouse under controlled conditions: $16 \mathrm{~h} / 24 \mathrm{~h}$ light, $24 / 19^{\circ} \mathrm{C}$ day/ night temperature, and $\mathrm{RH} 50 \%$. They were covered with opaque perforated plastic foil to prevent dessication. Eight weeks after potting, the percentage of acclimatized plants was scored.

Statistical analysis To compare the means, percentages of rooted cuttings were transformed according to Bliss (Wójcik and Laudański 1989) All of the data were subjected to one- or two-factorial ANOVA followed by Duncan's test at $\alpha=0.05$. The Statgraphics Centurion XVI program was used.

\section{Results}

Multiplication The type of sugar in the medium and its concentration significantly affected the in vitro regeneration (Table 3 ). The percentages of regenerating explants were the highest (98-100\%) in the control treatment and on the medium supplemented with 1 and $2 \%$ fructose or $1-4 \%$ sorbitol. The lowest regeneration $(60 \%)$ was on the medium with $5 \%$ sorbitol. The lowest number of axillary shoots was in the control treatment (1.4 per explant) and the highest on the medium enriched with $3 \%$ sorbitol (5.6 shoots per explant). The shortest shoots were produced on the medium with 1, 4, and $5 \%$ sorbitol $(1.9 \mathrm{~cm})$, while the longest were those on the medium with $4 \%$ fructose $(3.4 \mathrm{~cm})$ (Table 3$)$.

Sorbitol was chosen for the subsequent experiments not only because of its positive effect on the proliferation rate (Table 3 ) but also because of no effect on media solidification

Table 2 A list of treatments in the experiment on the ex vitro rooting

\begin{tabular}{lll}
\hline Treatment & Soaking & Spraying \\
\hline 1 & Distilled water & Distilled water \\
2 & $1 \mathrm{mg} \cdot \mathrm{L}^{-1} \mathrm{IBA}$ & \\
3 & $2 \mathrm{mg} \cdot \mathrm{L}^{-1} \mathrm{IBA}$ & \\
4 & Distilled water & $1 \mathrm{mg} \cdot \mathrm{L}^{-1} \mathrm{ABA}$ \\
5 & $1 \mathrm{mg} \cdot \mathrm{L}^{-1} \mathrm{IBA}$ & \\
6 & $2 \mathrm{mg} \cdot \mathrm{L}^{-1} \mathrm{IBA}$ & \\
\hline
\end{tabular}


Table 3 The effect of carbohydrate type and concentration on shoot proliferation in ninebark 'Dart's Gold'. The basal medium was MS supplemented with $1 \mathrm{mg} \cdot \mathrm{L}^{-1} \mathrm{BA}$ and $0.1 \mathrm{mg} \cdot \mathrm{L}^{-\mathbf{1}} \mathrm{NAA}$

\begin{tabular}{lllll}
\hline Carbohydrates & $\begin{array}{l}\text { Conc. } \\
(\%)\end{array}$ & Parameters & \\
& & $\begin{array}{c}\text { Regenerating } \\
\text { explants }(\%)^{* *}\end{array}$ & $\begin{array}{c}\text { Shoot } \\
\text { num- } \\
\text { ber }\end{array}$ & $\begin{array}{c}\text { Shoot } \\
\text { length } \\
(\mathrm{cm})\end{array}$ \\
Control & 0 & $100 \mathrm{e}^{*}$ & $1.4 \mathrm{a}$ & $2.6 \mathrm{de}$ \\
Fructose & 1 & $100 \mathrm{e}$ & $2.3 \mathrm{bc}$ & $2.5 \mathrm{de}$ \\
& 2 & $100 \mathrm{e}$ & $2.5 \mathrm{bc}$ & $2.6 \mathrm{de}$ \\
& 3 & $92 \mathrm{~cd}$ & $3.9 \mathrm{~d}$ & $2.7 \mathrm{e}$ \\
& 4 & $86 \mathrm{bc}$ & $4.3 \mathrm{~d}$ & $3.4 \mathrm{f}$ \\
& 5 & $86 \mathrm{bc}$ & $2.5 \mathrm{bc}$ & $2.3 \mathrm{c}$ \\
Sorbitol & 1 & $100 \mathrm{e}$ & $2.9 \mathrm{c}$ & $1.9 \mathrm{a}$ \\
& 2 & $100 \mathrm{e}$ & $4.5 \mathrm{~d}$ & $2.1 \mathrm{~b}$ \\
& 3 & $100 \mathrm{e}$ & $5.6 \mathrm{e}$ & $2.5 \mathrm{~d}$ \\
& 4 & $98 \mathrm{de}$ & $2.9 \mathrm{c}$ & $1.9 \mathrm{a}$ \\
& 5 & $60 \mathrm{a}$ & $2.2 \mathrm{~b}$ & $1.9 \mathrm{a}$ \\
Mean & 93 & & 3.2 & 2.4
\end{tabular}

* Means in a column followed by the same letter do not differ significantly at $\alpha=0.05$

** $100 \%$ was 50 explants

as observed in media with fructose. With $2-5 \%$ fructose, shoot vitrification and deformations were found, impeding further shoot growth.

The type of the culture medium had little effect on the multiplication rate (Table 4). The lowest rate (90\%) was observed on the NN medium; all remaining media produced $100 \%$ regeneration rate. The highest shoot number was produced on MS (6.1 per explant), while the lowest on QL (1.1

Table 4 The effect of culture medium on shoot proliferation in ninebark "Dart's Gold"

\begin{tabular}{llll}
\hline $\begin{array}{l}\text { Treatment } \\
\text { medium }\end{array}$ & Parameters & & \\
\cline { 2 - 4 } & $\begin{array}{l}\text { Regenerating explants } \\
(\%)^{* *}\end{array}$ & $\begin{array}{l}\text { Shoot } \\
\text { number }\end{array}$ & $\begin{array}{l}\text { Shoot length } \\
(\mathrm{cm})\end{array}$ \\
\hline $\mathrm{AN}$ & $100 \mathrm{~b}^{*}$ & $2.8 \mathrm{~b}$ & $2.9 \mathrm{~d}$ \\
$\mathrm{MS}$ & $100 \mathrm{~b}$ & $6.1 \mathrm{~d}$ & $2.3 \mathrm{c}$ \\
$\mathrm{NN}$ & $90 \mathrm{a}$ & $2.8 \mathrm{~b}$ & $2.2 \mathrm{bc}$ \\
$\mathrm{SH}$ & $100 \mathrm{~b}$ & $3.1 \mathrm{~b}$ & $2.1 \mathrm{bc}$ \\
QL & $100 \mathrm{~b}$ & $1.1 \mathrm{a}$ & $1.9 \mathrm{~b}$ \\
WPM & $100 \mathrm{~b}$ & $4.2 \mathrm{c}$ & $1.4 \mathrm{a}$ \\
Mean & 98 & 3.3 & 2.1
\end{tabular}

* Means in a column followed by the same letter do not differ significantly at $\alpha=0.05$

$* * 100 \%$ was 50 explants
Table 5 The effect of macronutrient concentration in MS medium on shoot proliferation in ninebark 'Dart's Gold'

\begin{tabular}{|c|c|c|c|}
\hline \multirow{2}{*}{$\begin{array}{l}\text { MS } \\
\text { concentration }\end{array}$} & \multicolumn{3}{|l|}{ Parameters } \\
\hline & $\begin{array}{l}\text { Regenerating explants } \\
(\%)^{* *}\end{array}$ & $\begin{array}{l}\text { Shoot } \\
\text { number }\end{array}$ & $\begin{array}{l}\text { Shoot length } \\
(\mathrm{cm})\end{array}$ \\
\hline $1 / 2 \mathrm{MS}$ & $90 \mathrm{a}$ & $2.5 \mathrm{a}$ & $1.6 \mathrm{a}$ \\
\hline $1 \mathrm{MS}$ & $100 \mathrm{~b}$ & $5.8 \mathrm{c}$ & $2.5 \mathrm{c}$ \\
\hline $1 \frac{1}{2} \mathrm{MS}$ & $98 \mathrm{ab}$ & $5.7 \mathrm{c}$ & $2.7 \mathrm{~d}$ \\
\hline $2 \mathrm{MS}$ & $92 \mathrm{a}$ & $4.7 \mathrm{~b}$ & $2.3 \mathrm{~b}$ \\
\hline Mean & 95 & 4.7 & 2.3 \\
\hline
\end{tabular}

* Means in a column followed by the same letter do not differ significantly at $\alpha=0.05$

** $100 \%$ was 50 explants

shoot per explant). The longest shoots were on AN $(2.9 \mathrm{~cm})$ while the shortest on WPM $(1.4 \mathrm{~cm})$. The MS medium appeared to be the best overall and was used in all subsequent experiments.

Macronutrient concentrations also affected proliferation (Table 5). On MS with at the standard concentration (1x) $100 \%$ explants while at one half or 2 strength, the regeneration rate was reduced to 90 and $92 \%$, respectively. The lowest number of shoots was produced on the medium with macronutrients reduced by half ( 2.5 per explant), and they were the shortest $(1.6 \mathrm{~cm})$. The explants cultured on $1 \mathrm{MS}$ and 1 1/2 MS developed the highest number of shoots (over 5.5 per explant), while the longest shoots $(2.7 \mathrm{~cm})$ were on $1 \frac{1}{2} \mathrm{MS}$.

There was a statistically significant effect of the medium pH on the regeneration rate (Table 6). At pH 5.8 and 6.2, all explants regenerated shoots; at $\mathrm{pH} 6.6$ this rate was reduced. The numbers of shoots were the highest at pH 5.4 and 5.8 (5.1 and 5.6, respectively), and the longest shoots $(2.3 \mathrm{~cm})$ were produced at $\mathrm{pH} 5.8 \mathrm{~cm}$.

Table 6 The effect of the medium $\mathrm{pH}$ on shoot proliferation in ninebark 'Dart's Gold'. The basal MS medium was supplemented with $1 \mathrm{mg} \cdot \mathrm{L}^{-1}$ $\mathrm{BA}$ and $0.1 \mathrm{mg} \cdot \mathrm{L}^{-1} \mathrm{NAA}$

\section{pH Parameters}

\begin{tabular}{llll}
\cline { 2 - 4 } & Regenerating explants $(\%)^{* *}$ & Shoot number & Shoot length $(\mathrm{cm})$ \\
\hline 5.4 & $94 \mathrm{ab}^{*}$ & $5.1 \mathrm{~b}$ & $2.1 \mathrm{~b}$ \\
5.8 & $100 \mathrm{~b}$ & $5.6 \mathrm{~b}$ & $2.3 \mathrm{c}$ \\
6.2 & $100 \mathrm{~b}$ & $3.8 \mathrm{a}$ & $1.9 \mathrm{ab}$ \\
6.6 & $90 \mathrm{a}$ & $3.7 \mathrm{a}$ & $1.8 \mathrm{a}$ \\
Mean & 96 & 4.6 & 2.0
\end{tabular}

* Means in a column followed by the same letter do not differ significantly at $\alpha=0.05$

$* * 100 \%$ was 50 explants 
The type and concentration of cytokinin in the culture medium significantly affected the regeneration rate (Table 7 , Fig. 1). The lowest percentage of regenerating explants was observed on the medium with $0.1 \mathrm{mg} \cdot \mathrm{L}^{-1} \mathrm{NAA}$ and supplemented with either $3 \mathrm{mg} \cdot \mathrm{L}^{-1}$ kinetin or $3 \mathrm{mg} \cdot \mathrm{L}^{-1} \mathrm{BA}(60 \%$ and $72 \%$ respectively). In treatments with $\mathrm{mT}$, TDZ, zeatin and $2 \mathrm{iP}$ the regeneration rate ranged between $84 \%$ and $100 \%$ with no significant differences between them. The lowest shoot number per explant, i.e., 1.1-1.2, was in the treatment with auxin only, and on media with kinetin in concentrations: $0.5,1.0$ and $3.0 \mathrm{mg} \cdot \mathrm{L}^{-1}$. The highest proliferation was on the

Table 7 The effect of the cytokinin type and concentration $\left(\mathrm{mg} \cdot \mathrm{L}^{-\mathbf{1}}\right)$ on shoot proliferation in ninebark 'Dart's Gold'. The basal medium was MS supplemented with $0.1 \mathrm{mg} \cdot \mathrm{L}^{-1} \mathrm{NAA}$; the control was without growth regulators

\begin{tabular}{|c|c|c|c|c|}
\hline \multicolumn{2}{|c|}{ Treatment } & \multicolumn{3}{|l|}{ Parameters } \\
\hline & & $\begin{array}{l}\text { Regenerating explants } \\
(\%)^{* *}\end{array}$ & $\begin{array}{l}\text { Shoot } \\
\text { number }\end{array}$ & $\begin{array}{l}\text { Shoot length } \\
(\mathrm{cm})\end{array}$ \\
\hline \multicolumn{2}{|c|}{$\begin{array}{c}\text { Control } \\
\text { MS } 0\end{array}$} & $92 \mathrm{~cd}^{*}$ & $1.1 \mathrm{a}$ & $2.1 \mathrm{bc}$ \\
\hline \multicolumn{2}{|c|}{$0.1 \mathrm{NAA}$} & $72 a b$ & $1.1 \mathrm{a}$ & $2.7 \mathrm{defg}$ \\
\hline \multirow[t]{4}{*}{ BA } & 0.5 & $84 \mathrm{bc}$ & $3.1 \mathrm{f}$ & $2.1 \mathrm{bc}$ \\
\hline & 1.0 & $100 \mathrm{~d}$ & $5.7 \mathrm{j}$ & $2.3 \mathrm{~cd}$ \\
\hline & 2.0 & $96 \mathrm{~cd}$ & $4.3 \mathrm{~h}$ & $2.3 \mathrm{~cd}$ \\
\hline & 3.0 & $72 a b$ & $3.5 \mathrm{~g}$ & $1.8 \mathrm{~b}$ \\
\hline \multirow[t]{4}{*}{ Kin } & 0.5 & $86 \mathrm{~cd}$ & $1.1 \mathrm{a}$ & $3.1 \mathrm{fgh}$ \\
\hline & 1.0 & $88 \mathrm{~cd}$ & $1.2 \mathrm{a}$ & $3.1 \mathrm{fgh}$ \\
\hline & 2.0 & $92 \mathrm{~cd}$ & $1.6 \mathrm{~b}$ & $3.2 \mathrm{gh}$ \\
\hline & 3.0 & $60 \mathrm{a}$ & $1.1 \mathrm{a}$ & $3.4 \mathrm{~h}$ \\
\hline \multirow[t]{4}{*}{$\mathrm{mT}$} & 0.5 & $88 \mathrm{~cd}$ & $2.4 \mathrm{de}$ & $3.1 \mathrm{fgh}$ \\
\hline & 1.0 & $84 \mathrm{bc}$ & $2.4 \mathrm{de}$ & $3.0 \mathrm{fgh}$ \\
\hline & 2.0 & $96 \mathrm{~cd}$ & $5.9 \mathrm{j}$ & $2.4 \mathrm{cde}$ \\
\hline & 3.0 & $96 \mathrm{~cd}$ & $2.6 \mathrm{e}$ & $2.0 \mathrm{bc}$ \\
\hline \multirow[t]{4}{*}{ TDZ } & 0.5 & $100 \mathrm{~d}$ & 17.91 & $0.9 \mathrm{a}$ \\
\hline & 1.0 & $100 \mathrm{~d}$ & $18.4 \mathrm{~m}$ & $1.0 \mathrm{a}$ \\
\hline & 2.0 & $100 \mathrm{~d}$ & $19.1 \mathrm{n}$ & $0.9 \mathrm{a}$ \\
\hline & 3.0 & $100 \mathrm{~d}$ & $16.2 \mathrm{k}$ & $0.8 \mathrm{a}$ \\
\hline \multirow[t]{4}{*}{ Zea } & 0.5 & $100 \mathrm{~d}$ & $2.4 \mathrm{de}$ & $1.9 \mathrm{bc}$ \\
\hline & 1.0 & $96 \mathrm{~cd}$ & $3.2 \mathrm{f}$ & $3.4 \mathrm{~h}$ \\
\hline & 2.0 & $100 \mathrm{~d}$ & $5.2 \mathrm{i}$ & $4.3 \mathrm{i}$ \\
\hline & 3.0 & $100 \mathrm{~d}$ & $5.0 \mathrm{i}$ & $4.2 \mathrm{i}$ \\
\hline \multirow[t]{4}{*}{$2 \mathrm{iP}$} & 0.5 & $88 \mathrm{~cd}$ & $2.4 \mathrm{de}$ & $2.7 \mathrm{def}$ \\
\hline & 1.0 & $96 \mathrm{~cd}$ & $2.3 \mathrm{~cd}$ & $2.7 \mathrm{def}$ \\
\hline & 2.0 & $92 \mathrm{~cd}$ & $2.0 \mathrm{c}$ & $3.1 \mathrm{fgh}$ \\
\hline & 3.0 & $92 \mathrm{~cd}$ & $2.0 \mathrm{c}$ & $2.8 \mathrm{efg}$ \\
\hline \multicolumn{2}{|c|}{ Mean } & 91 & 5.1 & 2.5 \\
\hline
\end{tabular}

*Means in a column followed by the same letter do not differ significantly at $\alpha=0.05$

**100\% was 50 explants medium with TDZ with number of shoots per explant reaching 19.1 .

While TDZ produced the highest numbers of shoots these shoots were very short and malformed, that would impede their separation and transfer to new culture vessels. From the practical point of view, the TDZ effect was regarded as useless and compound was excluded from subsequent experiments. High numbers of shoots were also obtained in treatments with $1 \mathrm{mg} \cdot \mathrm{L}^{-1} \mathrm{BA}$ or $2 \mathrm{mg} \cdot \mathrm{L}^{-1} \mathrm{mT}$ in the medium and they were almost 5.5 times higher than the control without growth regulators and with no negative side effects.

Efficient proliferation was also observed on media supplemented with 2 and $3 \mathrm{mg} \cdot \mathrm{L}^{-1}$ zeatin (almost 5 times more than in the control). The longest shoots were produced with 2 and $3 \mathrm{mg} \cdot \mathrm{L}^{-1}$ zeatin ( 4.3 and $4.2 \mathrm{~cm}$ respectively). Plants taller by nearly $50 \%$ than in the control were also produced on the medium with kinetin at all concentrations tested, $0.5-1 \mathrm{mg}$. $\mathrm{L}^{-1}$ meta-Topolin, $1 \mathrm{mg} \cdot \mathrm{L}^{-1}$ zeatin, and $2 \mathrm{mg} \cdot \mathrm{L}^{-1} 2 \mathrm{iP}(3.0$ $3.4 \mathrm{~cm})$. Generally, kinetin supplementation increased the shoot length but not shoot formation. The best treatment for both the shoot number and length was the medium with 2 and $3 \mathrm{mg} \cdot \mathrm{L}^{-1}$ zeatin.

$\mathbf{G A}_{3}$ had no effect on the regeneration rate which ranged between 92 and $100 \%$ with no significant differences between the treatments (Table 8). However. there was a positive effect of $\mathrm{GA}_{3}$ on proliferation: the highest shoot number per explant (12.1) was produced at $1 \mathrm{mg} \cdot \mathrm{L}^{-1} \mathrm{GA}_{3}$ - almost ten times higher than on media without growth regulators. The shoot lengths $(2.1-2.4 \mathrm{~cm})$ were comparable in all treatments.

There was no effect of the culture age (the number of passages) on the regeneration rate (Table 9). However, the shoot number per explant and shoot length were affected. On the average, explants produced 3.2-6.8 shoots, depending on the passage. The lowest shoot number, which were also the shortest, was in the first passage when the culture has not yet fully established. In the second and third passages, the proliferation rate increased, and then it kept decreasing until the 8th passage. Statistically, the highest numbers of shoots were produced between passages 10 and 17. Between passages 18 and 20 , drop in the proliferation rate was again observed. Generally, during the entire experiment, the explants averaged 5.6 shoots. The mean shoot length ranged between 1.7 and $2.3 \mathrm{~cm}$. The shortest shoots were in the first passage, and then their length kept increased until passage 8 , reaching $2.3 \mathrm{~cm}$. Similar shoot lengths were produced in passages $12-13$ and 18-20.

Rooting Auxin affected all tested parameters of rooting (Table 10, Fig. 2). The lowest percentage of rooted cuttings was observed on the control medium $(46 \%)$ and on media with 0.1 and $3 \mathrm{mg} \cdot \mathrm{L}^{-1}$ IBA $(56 \%$ and $64 \%)$ or 0.1 and $3 \mathrm{mg} \cdot \mathrm{L}^{-1} \mathrm{NAA}$ ( $62 \%$ in both treatments). The highest rooting percentage was on media supplemented with either 1 and 

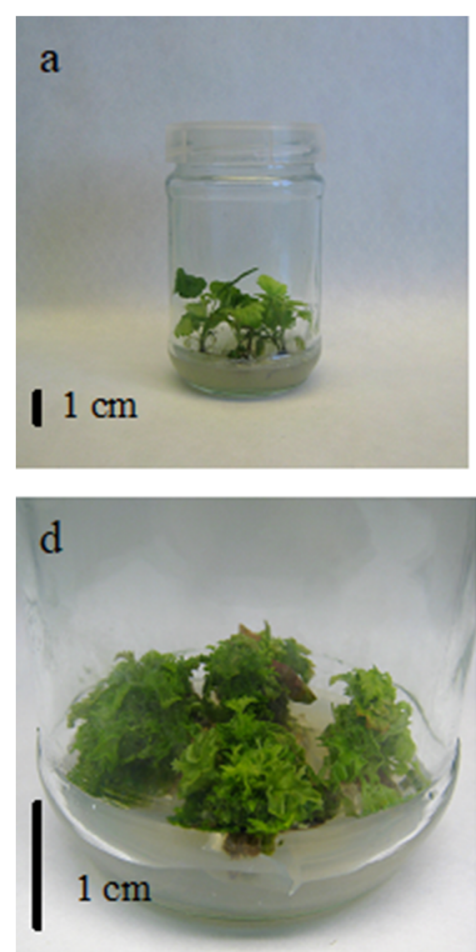
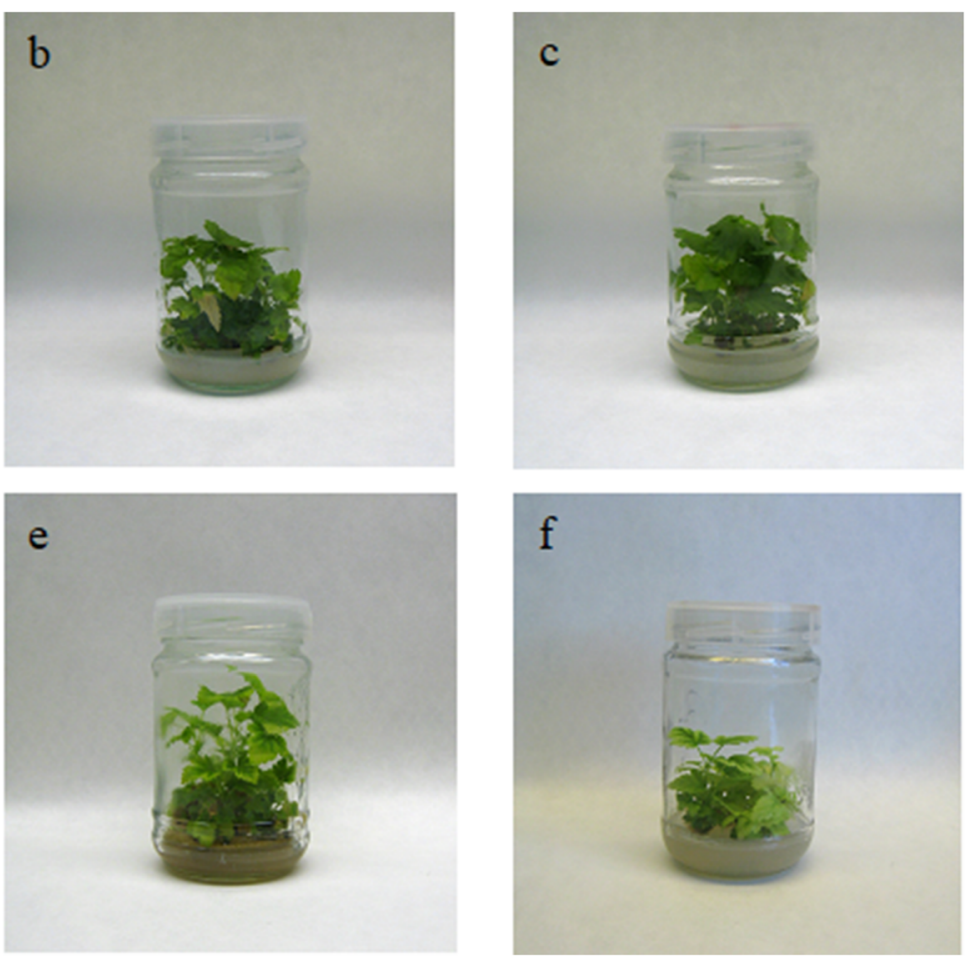

Figure. 1 Proliferating shoots of ninebark "Dart's Gold" after 8-week culture on the medium: (a) without growth regulators (control); supplemented with: (b) $1 \mathrm{mg} \cdot \mathrm{L}^{-1} \mathrm{BA}$; (c) $2 \mathrm{mg} \cdot \mathrm{L}^{-1} \mathrm{mT}$; (d) $1 \mathrm{mg} \cdot \mathrm{L}^{-1} \mathrm{TDZ}$; (e) $2 \mathrm{mg} \cdot \mathrm{L}^{-1} \mathrm{Zea}$; (f) $1 \mathrm{mg} \cdot \mathrm{L}^{-1} 2 \mathrm{iP}$

$2 \mathrm{mg} \cdot \mathrm{L}^{-1} \mathrm{IBA}(96 \%$ and $92 \%)$ or 1 and $2 \mathrm{mg} \cdot \mathrm{L}^{-1} \mathrm{NAA}(88 \%$ and $96 \%$ ). The highest root numbers per cutting were produced in the presence of $3 \mathrm{mg} \cdot \mathrm{L}^{-1}$ IBA or NAA (13 and 12 roots), the lowest on the control medium (3.3 root), or in the presence of $0.1 \mathrm{mg} \cdot \mathrm{L}^{-1}$ IBA (4.3 roots). The longest roots were produced on the medium with $0.1 \mathrm{mg} \cdot \mathrm{L}^{-1}$ IBA $(1.3 \mathrm{~cm})$, while the shortest in the presence of $0.1,0.5,1$, and 3 NAA $\mathrm{mg} \cdot \mathrm{L}^{-1}(0.2-0.3 \mathrm{~cm})$.

The macronutrient concentration significantly affected rooting parameters (Table 11). On the medium with one fourth MS only, $60 \%$ cuttings developed roots and those roots were fewer (3.5 roots per cutting) and shorter $(0.4 \mathrm{~cm})$ than in cuttings cultured on other media. Plants from one half MS and MS did not differ in the percentage of rooted cuttings (96\%) nor in mean root number and length (8.8 and 8.9 roots 1.2 and 1.3-cm-long, respectively).

Spraying plants with ABA significantly affected all acclimation parameters tested (Table 12). In control treatments, only $80 \%$ of plants became adapted to the greenhouse conditions, while in all other treatments, all plants were successfully adapted. The shortest were plants sprayed with 0.5 and $2 \mathrm{mg} \cdot \mathrm{L}^{-1} \mathrm{ABA}$, and their height was approximately $93 \%$ of that in control plants. The highest were plants sprayed with $1 \mathrm{mg} \cdot \mathrm{L}^{-1} \mathrm{ABA}(9 \mathrm{~cm}$ on the average). The lowest internode

Table 8 The effect of $\mathrm{GA}_{3}$ on shoot proliferation in ninebark "Dart's Gold"

\begin{tabular}{|c|c|c|c|c|c|c|}
\hline \multirow[t]{2}{*}{ No } & \multirow[t]{2}{*}{$\mathrm{NAA}\left(\mathrm{mg} \cdot \mathrm{L}^{-1}\right)$} & \multirow[t]{2}{*}{$\mathrm{BA}\left(\mathrm{mg} \cdot \mathrm{L}^{-1}\right)$} & \multirow[t]{2}{*}{$\mathrm{GA}_{3}\left(\mathrm{mg} \cdot \mathrm{L}^{-1}\right)$} & \multicolumn{3}{|l|}{ Parameters } \\
\hline & & & & Regenerating explants $(\%) * *$ & Shoot number & Shoot length $(\mathrm{cm})$ \\
\hline 1 & 0 & 0 & 0 & $92 \mathrm{a}^{*}$ & $1.3 \mathrm{a}$ & $2.3 \mathrm{a}$ \\
\hline 2 & 0.1 & 1.0 & 0 & $100 \mathrm{a}$ & $6.1 \mathrm{~b}$ & $2.4 \mathrm{a}$ \\
\hline 3 & & & 0.25 & $96 \mathrm{a}$ & $8.5 \mathrm{c}$ & $2.2 \mathrm{a}$ \\
\hline 4 & & & 0.5 & $100 \mathrm{a}$ & $11.0 \mathrm{~d}$ & $2.3 \mathrm{a}$ \\
\hline 5 & & & 1.0 & $100 \mathrm{a}$ & $12.1 \mathrm{e}$ & $2.1 \mathrm{a}$ \\
\hline 6 & & & 2.0 & $96 \mathrm{a}$ & $9.0 \mathrm{c}$ & $2.1 \mathrm{a}$ \\
\hline Mean & & & & 97 & 8.0 & 2.2 \\
\hline
\end{tabular}

* Means in a column followed by the same letter do not differ significantly at $\alpha=0.05$

**100\% was 50 explants 
Table 9 The effect of the number of passages on shoot proliferation in ninebark "Dart's Gold." The basal medium was MS supplemented with $1 \mathrm{mg} \cdot \mathrm{L}^{-1} \mathrm{BA}$ and $0.1 \mathrm{mg} \cdot \mathrm{L}^{-1} \mathrm{NAA}$

\begin{tabular}{llll}
\hline $\begin{array}{l}\text { Passage } \\
\text { number }\end{array}$ & Parameters & & \\
\cline { 2 - 4 } & $\begin{array}{l}\text { Regenerating explants } \\
(\%)^{* *}\end{array}$ & $\begin{array}{l}\text { Shoot } \\
\text { number }\end{array}$ & $\begin{array}{l}\text { Shoot length } \\
(\mathrm{cm})\end{array}$ \\
\hline 1 & $98 \mathrm{a}^{*}$ & $3.2 \mathrm{a}$ & $1.7 \mathrm{a}$ \\
2 & $100 \mathrm{a}$ & $5.5 \mathrm{def}$ & $2.3 \mathrm{de}$ \\
3 & $100 \mathrm{a}$ & $5.6 \mathrm{efg}$ & $2.3 \mathrm{de}$ \\
4 & $100 \mathrm{a}$ & $4.8 \mathrm{bc}$ & $2.2 \mathrm{cde}$ \\
5 & $100 \mathrm{a}$ & $4.5 \mathrm{~b}$ & $2.3 \mathrm{e}$ \\
6 & $100 \mathrm{a}$ & $4.3 \mathrm{~b}$ & $2.2 \mathrm{cde}$ \\
7 & $100 \mathrm{a}$ & $4.7 \mathrm{bc}$ & $2.2 \mathrm{cde}$ \\
8 & $100 \mathrm{a}$ & $4.9 \mathrm{bcd}$ & $2.3 \mathrm{e}$ \\
9 & $100 \mathrm{a}$ & $5.4 \mathrm{cde}$ & $2.1 \mathrm{bcd}$ \\
10 & $100 \mathrm{a}$ & $6.8 \mathrm{j}$ & $1.9 \mathrm{~b}$ \\
11 & $100 \mathrm{a}$ & $6.8 \mathrm{ij}$ & $1.9 \mathrm{~b}$ \\
12 & $100 \mathrm{a}$ & $6.6 \mathrm{ij}$ & $2.2 \mathrm{cde}$ \\
13 & $98 \mathrm{a}$ & $6.8 \mathrm{j}$ & $2.3 \mathrm{e}$ \\
14 & $100 \mathrm{a}$ & $6.2 \mathrm{hij}$ & $1.9 \mathrm{~b}$ \\
15 & $100 \mathrm{a}$ & $6.3 \mathrm{ij}$ & $2.0 \mathrm{bc}$ \\
16 & $100 \mathrm{a}$ & $6.6 \mathrm{ij}$ & $2.0 \mathrm{bc}$ \\
17 & $100 \mathrm{a}$ & $6.1 \mathrm{ghi}$ & $2.0 \mathrm{bc}$ \\
18 & $100 \mathrm{a}$ & $5.4 \mathrm{cde}$ & $2.3 \mathrm{e}$ \\
19 & $100 \mathrm{a}$ & $5.2 \mathrm{cde}$ & $2.1 \mathrm{bcde}$ \\
20 & $98 \mathrm{a}$ & $5.3 \mathrm{cde}$ & $2.2 \mathrm{cde}$ \\
Mean & 99.7 & 5.6 & 2.1 \\
\hline & & & \\
\hline & & & \\
& & &
\end{tabular}

*Means in a column followed by the same letter do not differ significantly at $\alpha=0.05$

$* * 100 \%$ was 50 explants

number was found in plants treated with $2 \mathrm{mg} \cdot \mathrm{L}^{-1}, \mathrm{ABA}$ while this value did not differ in other treatments.

The effect of spraying with ABA and of supplementary lightning on acclimation to the ex vitro conditions is shown in Table 13. The lowest percentage of acclimatized plants (76\%) was in plants not given extra light and sprayed with water. In all remaining treatments, all plants were properly acclimated. Two months after planting the smallest plants with the lowest internode number were observed in the treatment where plants were sprayed with $\mathrm{ABA}$ and not given extra light: the average height of plants was $7.4 \mathrm{~cm}$ and they had 9.4 internodes. The best growth was in plants sprayed with $\mathrm{ABA}$ and grown under supplementary lighting: they were $14.3-\mathrm{cm}$ tall and averaged 12.2 internodes.

Treatments with IBA and ABA significantly affected rhizogenesis ex vitro (Table 14, Fig. 3). The lowest percentages of rooted and acclimated plants were in treatments where cuttings were soaked in water and sprayed with water or ABA (30 and 38\%, respectively). The highest percentage of cuttings rooted ex vitro was in plants soaked in the solution of $1 \mathrm{mg}$.
Table 10 The effect of auxin on rooting of axillary shoots in ninebark "Dart's Gold"

\begin{tabular}{|c|c|c|c|}
\hline \multirow{2}{*}{$\begin{array}{l}\text { Treatment } \\
\left(\mathbf{m g} \cdot \mathrm{L}^{-1}\right)\end{array}$} & \multicolumn{3}{|l|}{ Parameters } \\
\hline & $\begin{array}{l}\text { Rooted cuttings } \\
(\%)^{* *}\end{array}$ & $\begin{array}{l}\text { Root } \\
\text { number }\end{array}$ & $\begin{array}{l}\text { Root length } \\
(\mathrm{cm})\end{array}$ \\
\hline Control & $46 a$ & $3.3 \mathrm{a}$ & $1.2 \mathrm{~d}$ \\
\hline $0.1 \mathrm{IBA}$ & $56 \mathrm{a}$ & $4.3 \mathrm{a}$ & $0.6 \mathrm{bc}$ \\
\hline 0.5 IBA & $82 \mathrm{~cd}$ & $6.2 \mathrm{~b}$ & $0.8 \mathrm{c}$ \\
\hline $1 \mathrm{IBA}$ & $96 \mathrm{e}$ & $9.2 \mathrm{c}$ & $1.3 \mathrm{e}$ \\
\hline 2 IBA & $92 \mathrm{de}$ & $10.0 \mathrm{c}$ & $0.7 \mathrm{bc}$ \\
\hline 3 IBA & $64 \mathrm{ab}$ & $13.0 \mathrm{~d}$ & $0.6 \mathrm{~b}$ \\
\hline $0.1 \mathrm{NAA}$ & $62 \mathrm{ab}$ & $6.2 \mathrm{~b}$ & $0.3 \mathrm{a}$ \\
\hline $0.5 \mathrm{NAA}$ & $76 \mathrm{bc}$ & $5.9 \mathrm{~b}$ & $0.3 \mathrm{a}$ \\
\hline $1 \mathrm{NAA}$ & $88 \mathrm{de}$ & $6.0 \mathrm{~b}$ & $0.2 \mathrm{a}$ \\
\hline 2 NAA & $96 \mathrm{e}$ & $9.0 \mathrm{c}$ & $0.5 \mathrm{~b}$ \\
\hline 3 NAA & $62 a b$ & $12.0 \mathrm{~d}$ & $0.3 \mathrm{a}$ \\
\hline Mean & 75 & 7.7 & 0.6 \\
\hline
\end{tabular}

*Means in a column followed by the same letter do not differ significantly at $\alpha=0.05$

$* * 100 \%$ was 50 explants

$\mathrm{L}^{-1}$ IBA and sprayed with distilled water $(80 \%)$ as well as in plants soaked in 1 and $2 \mathrm{mg} \cdot \mathrm{L}^{-1}$ IBA and sprayed with $1 \mathrm{mg}$. $\mathrm{L}^{-1}$ ABA (74 and 64\%). Significantly fewer roots were produced by cuttings soaked in water and sprayed with water or $\mathrm{ABA}$, as well as those soaked in $2 \mathrm{mg} \cdot \mathrm{L}^{-1} \mathrm{IBA}$ and then sprayed with ABA. The highest root numbers were observed after soaking in 1 or $2 \mathrm{mg} \cdot \mathrm{L}^{-1}$ IBA and spraying with water (3.6 roots per plant). The shortest roots were produced in plants soaked in water and sprayed with water and in those soaked in $2 \mathrm{mg} \cdot \mathrm{L}^{-1}$ IBA and sprayed with $\mathrm{ABA}$ ( 0.8 and $0.9 \mathrm{~cm}$, respectively). The longest roots developed in cuttings soaked in $1 \mathrm{mg} \cdot \mathrm{L}^{-1}$ IBA and sprayed with water $(1.7 \mathrm{~cm})$ and in those soaked in water and sprayed with $\mathrm{ABA}(1.5 \mathrm{~cm})$.

\section{Discussion}

The main goal of micropropagation is to obtain quickly and as efficiently as possible, a maximal amount of good quality plant material. Numerous factors affect the efficiency of the process, such as the type and concentration of carbohydrates, macronutrient composition, medium $\mathrm{pH}$, composition and dosages of growth regulators as well as duration and the number of passages, individually and in combinations. Overall, the optimization of the process can be rather tedious.

According to Ilczuk et al. (2013), the most suitable carbohydrate source for micropropagation of ninebark $\mathrm{cv}$. "DIABLE D"OR "Mindia" was fructose; its presence in the medium yielded the highest percentage of regenerating 

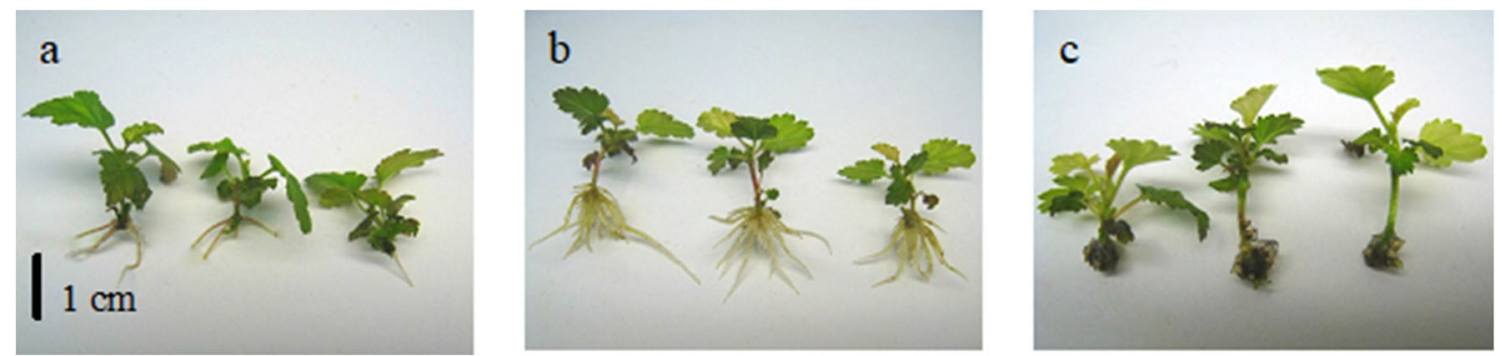

Figure. 2 Plants of ninebark 'Dart's Gold' after 8 wk of rooting on the medium: (a) control, without auxin; (b) supplemented with $1 \mathrm{mg} \cdot \mathrm{L}^{-1} \mathrm{IBA}$; and (c) with $1 \mathrm{mg} \cdot \mathrm{L}^{-1} \mathrm{NAA}$

explants relative to glucose, maltose, and sucrose. Fructose also performed the best during the rooting stage. However, media with fructose often lead to vitrification and this reduces plant vigor. This was reported earlier by Pierik (1997). Moreover, problems with solidifying media containing fructose were observed during ninebark multiplication (Ilczuk et al. 2013), perhaps due to fructose degradation during autoclaving and appearance of toxic furans (Rédei 1979). Here, another carbohydrate source, sorbitol, was tested, and it resulted in good proliferation while avoiding the solidification issues. According to Ahmad et al. (2007) and Yaseen et al. (2009), many plants from the Rosaceae family multiply well in the presence of sorbitol. For cv. "Dart's Gold" tested here, the best medium was the MS with 3\% sorbitol, producing $100 \%$ regeneration and the highest shoot number per explant. Similar results were obtained by Ahmad et al. (2007) on peach and by Yaseen et al. (2009) on apple rootstocks M9 and M26. The positive effect of sorbitol in the Rosaceae may be related to the fact that it is their main photo assimilate (Moing et al. 1992) or because the enzymes responsible for its hydrolysis are already in place (Ahmad et al. 2007). The activity of such enzymes was confirmed in tissues of the sorbitol-translocating plants (Stoop and Pharr 1993).

The nutrient composition of a culture medium is decisive for the number and quality of shoots produced in the multiplication phase. Cv. "Dart's Gold" tested here showed the best proliferation on the MS even though WPM is often reported as

Table 11 The effect of macronutrient concentrations on rooting of shoots in ninebark "Dart's Gold"

\begin{tabular}{llll}
\hline $\begin{array}{l}\text { MS } \\
\text { concentration }\end{array}$ & $\begin{array}{l}\text { Rooted cuttings } \\
(\%)^{* *}\end{array}$ & $\begin{array}{l}\text { Parameters } \\
\text { Root } \\
\text { number }\end{array}$ & $\begin{array}{l}\text { Root length } \\
(\mathrm{cm})\end{array}$ \\
\hline $1 / 4 \mathrm{MS}$ & $60 \mathrm{a}$ & $3.5 \mathrm{a}$ & $0.4 \mathrm{a}$ \\
$1 / 2 \mathrm{MS}$ & $96 \mathrm{~b}$ & $8.8 \mathrm{~b}$ & $1.2 \mathrm{~b}$ \\
MS & $96 \mathrm{~b}$ & $8.9 \mathrm{~b}$ & $1.3 \mathrm{~b}$ \\
Mean & 84 & 7.1 & 1.0 \\
\hline
\end{tabular}

* Means in a column followed by the same letter do not differ significantly at $\alpha=0.05$

**100\% was 50 cuttings the most suitable medium for woody plants. Similar results were obtained by Kassim et al. (2010) on Prunus amygdalus or by Gallo et al. (2017) on the rootstock Prunus "Mr.S.2/5," where MS gave significantly better proliferation than WPM or other media. This may be a consequence of a higher macronutrient contents of MS. $\mathrm{NH}_{4}{ }^{+}$ions included. According to Mercier et al. (1997) the nitrogen source $\left(\mathrm{NO}_{3}{ }^{-}, \mathrm{NH}_{4}{ }^{+}\right)$directly affects the levels of endogenous IAA and cytokinins; hence, differences in salt concentrations may induce different plant responses during the multiplication phase (Matt and Jehle 2005).

The salt concentration in the medium is decisive for shoot proliferation. Here, the proliferation rate was the highest on MS at full concentration, as well as on $1 \frac{1}{2}$ MS, the latter resulting also in the longest shoots. On the other hand, reduced salt concentration such as in $1 / 2 \mathrm{MS}$ or increased concentration to $2 \mathrm{~s}$ reduced the regeneration rate by approx. $10 \%$. The lowest shoot number was produced on the medium with the macronutrients reduced by one half and they were the shortest. However, in some leguminose trees, the half-strength MS medium worked well (Yuji et al. 1993); in dogwood, there was no difference in shoot numbers between $1 \mathrm{x}$ and $1 / 2 \mathrm{MS}$ (Declerck and Korban 1996).

The medium $\mathbf{p H}$ affects the availability and uptake of nutrients by plant tissues, and sometimes a small change in pH may significantly affect plant growth, instead towards

Table 12 The effect of spraying in vitro rooted ninebark cuttings with $\mathrm{ABA}$ on their acclimation to the ex vitro conditions

\begin{tabular}{llll}
\hline $\begin{array}{l}\text { Treatment - ABA } \\
\left(\mathbf{m g} \cdot \mathbf{L}^{-\mathbf{1}}\right)\end{array}$ & $\begin{array}{l}\text { Acclimatized plants } \\
(\%)^{* *}\end{array}$ & $\begin{array}{l}\text { Parameters } \\
\text { Plant height } \\
(\mathrm{cm})\end{array}$ & $\begin{array}{l}\text { Internode } \\
\text { number }\end{array}$ \\
\hline Control - 0 & $80 \mathrm{a}^{*}$ & $8.4 \mathrm{~b}$ & $9.4 \mathrm{~b}$ \\
0.5 & $100 \mathrm{~b}$ & $7.7 \mathrm{a}$ & $9.2 \mathrm{~b}$ \\
1.0 & $100 \mathrm{~b}$ & $9.0 \mathrm{c}$ & $9.4 \mathrm{~b}$ \\
2.0 & $100 \mathrm{~b}$ & $7.9 \mathrm{a}$ & $8.8 \mathrm{a}$ \\
Mean & 95 & 8.3 & 9.2 \\
\hline$*$ Means in a column followed by the same letter do not differ significantly \\
at $\alpha=0.05$ \\
$* * 100 \%$ was 50 cuttings
\end{tabular}


Table 13 The effect of ABA $\left(1 \mathrm{mg} \cdot \mathrm{L}^{-\mathbf{1}}\right)$ and supplementary lighting on ninebark acclimation to the ex vitro conditions

\begin{tabular}{|c|c|c|c|c|}
\hline \multicolumn{2}{|c|}{ Treatment } & \multicolumn{3}{|l|}{ Parameters } \\
\hline $\begin{array}{l}\text { Sprayed } \\
\text { with }\end{array}$ & Lighted & $\begin{array}{l}\text { Acclimatized plants } \\
(\%)^{* *}\end{array}$ & $\begin{array}{l}\text { Plant height } \\
\quad(\mathrm{cm})\end{array}$ & $\begin{array}{l}\text { Internode } \\
\text { number }\end{array}$ \\
\hline $\mathrm{H}_{2} \mathrm{O}$ & - & $76 a^{*}$ & $8.0 \mathrm{~b}$ & $10.1 \mathrm{~b}$ \\
\hline $\mathrm{ABA}$ & & $100 \mathrm{~b}$ & $7.4 \mathrm{a}$ & $9.4 \mathrm{a}$ \\
\hline $\mathrm{H}_{2} \mathrm{O}$ & + & $100 \mathrm{~b}$ & $13.3 \mathrm{c}$ & $11.6 \mathrm{c}$ \\
\hline $\mathrm{ABA}$ & & $100 \mathrm{~b}$ & $14.3 \mathrm{~d}$ & $12.2 \mathrm{~d}$ \\
\hline Mean & & 94 & 10.8 & 10.8 \\
\hline
\end{tabular}

* Means followed by the same letter do not differ significantly at $\alpha=0.05$ $* * 100 \%$ was 50 cuttings

growth. The energy is directed towards adaptation to the medium $\mathrm{pH}$ (Thorpe et al. 2008). According to Javed et al. (2013), the medium $\mathrm{pH}$ significantly affected multiplication in Acacia ehrenbergiana with optimum at $\mathrm{pH}$ 5.8. The same $\mathrm{pH}$ worked well in magnolia (Cui et al. 2019). In Amygdalus communis $\mathrm{pH} 5.5$ was the best for the initiation and multiplications phases; lower and higher $\mathrm{pH}$ produced some disorders (Gürel and Gülșen 1998). Here, in "Dart's Gold," the multiplication ratio and shoot length were higher at lower $\mathrm{pH}$ (5.45.8).

Cytokinin type and concentration do have specific effects on organogenesis in vitro in various taxa; their uptake, transport, and metabolism differ among species, cultivars, or even tissues. As cytokinins induce cell divisions, hence bud and shoot formation, they are indispensable in micropropagation (Davies 2010). Among various cytokinins, benzyladenine (BA) is one of the most efficient and is readily available (Werbrouck et al. 1996). In this study, both the type and concentration of cytokinin affected shoot proliferation.

Table 14 The effect of treatments with IBA $\left(\mathrm{mg} \cdot \mathrm{L}^{-1}\right)$ and ABA $\left(\mathrm{mg} \cdot \mathrm{L}^{-1}\right)$ on the ex vitro rooting and acclimation to greenhouse conditions of cuttings in ninebark "Dart's Gold"

\begin{tabular}{|c|c|c|c|c|}
\hline \multicolumn{2}{|c|}{ Treatment } & \multicolumn{3}{|l|}{ Parameters } \\
\hline Soaking & Spraying & $\begin{array}{l}\text { Rooted cuttings } \\
(\%)^{* *}\end{array}$ & $\begin{array}{l}\text { Root } \\
\text { number }\end{array}$ & $\begin{array}{l}\text { Root length } \\
\quad(\mathrm{cm})\end{array}$ \\
\hline $\mathrm{H}_{2} \mathrm{O}$ & $\mathrm{H}_{2} \mathrm{O}$ & $30 \mathrm{a}$ & $2.5 \mathrm{a}$ & $0.8 \mathrm{a}$ \\
\hline $1 \mathrm{IBA}$ & & $80 \mathrm{c}$ & $4.2 \mathrm{c}$ & $1.7 \mathrm{c}$ \\
\hline 2 IBA & & $50 \mathrm{ab}$ & $4.2 \mathrm{c}$ & $1.2 \mathrm{~b}$ \\
\hline $\mathrm{H}_{2} \mathrm{O}$ & $1 \mathrm{ABA}$ & $38 \mathrm{a}$ & $2.5 \mathrm{a}$ & $1.5 \mathrm{c}$ \\
\hline $1 \mathrm{IBA}$ & & $74 \mathrm{bc}$ & $3.6 \mathrm{bc}$ & $1.2 \mathrm{~b}$ \\
\hline 2 IBA & & $64 \mathrm{bc}$ & $2.9 \mathrm{ab}$ & $0.9 \mathrm{ab}$ \\
\hline Mean & & 56 & 3.3 & 1.2 \\
\hline
\end{tabular}

* Means in a column followed by the same letter do not differ significantly at $\alpha=0.05$

$* * 100 \%$ was 50 cuttings

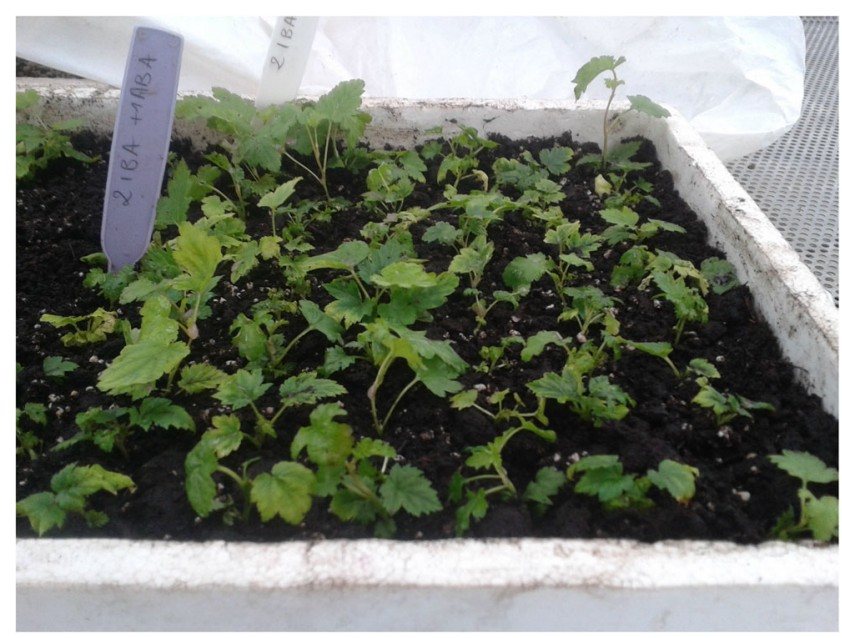

Figure. 3 Cuttings of ninebark 'Dart's Gold' after 2 weeks of ex vitro rooting

The highest multiplication ratio was observed with TDZ, but resulting plants were shorter and differed morphologically from standard phenotype, and this cytokinin was dropped from further tests. Similar abnormalities were observed in Cornus florida (Kaveriappa et al. 1997) or Cotoneaster wilsonii (Sivanesan et al. 2011). In this study high numbers of good quality shoots were obtained on medium with $1 \mathrm{mg}$. $\mathrm{L}^{-1} \mathrm{BA}$ and $2 \mathrm{mg} \cdot \mathrm{L}^{-1} \mathrm{mT}$ while the longest shoots were produced in the presence of $2-3 \mathrm{mg} \cdot \mathrm{L}^{-1}$ zeatin. A positive effect of $\mathrm{mT}$ on regeneration was reported in pear rootstock OHF333 (Dimitrova et al. 2016) and smoke tree "Royal Purple" (Podwyszyńska et al. 2012). Explants of Pelargonium placed on the mT-containing medium produced twice as many shoots as those on BA (Wojtania 2010). Zeatin affects not only shoot elongation as here in ninebark, in olive cultivars (Micheli et al. 2010), and apricot (Murai et al. 1997) but also increases the multiplication ratio as in Cissus quadrangularis (Garg and Malik 2012). For efficient propagation of a given taxon, different cytokinin concentrations may be suitable. In Catalpa ovata, a high zeatin concentration of $5 \mathrm{mg} \cdot \mathrm{L}^{-1}$ was needed to stimulate proliferation (Lisowska and Wysokinska 2000). In Acacia ehrenbergiana, three cytokinins tested (BA, Kin, and 2iP) were the most efficient when used in concentration $2 \mathrm{mg}$. $\mathrm{L}^{-1}$. The authors suggested that optimal concentrations of different cytokinins are comparable as there is a threshold cytokinin concentration which can be tolerated by plant. When exceeded, it provokes a plant defense response which needs energy normally used for shoot growth and development (Javed et al. 2013). Our results are not in line with this speculation as an optimal concentration depended on a cytokinin type. The best proliferation in ninebark "Dart's Gold" occurred by the following concentrations: $1 \mathrm{mg} \cdot \mathrm{L}^{-1} \mathrm{BA}, 2$ $3 \mathrm{mg} \cdot \mathrm{L}^{-1} \mathrm{Kin}, 2 \mathrm{mg} \cdot \mathrm{L}^{-1} \mathrm{mT}, 2-3 \mathrm{mg} \cdot \mathrm{L}^{-1} \mathrm{TDZ}, 2 \mathrm{mg} \cdot \mathrm{L}^{-1}$ Zea, and $0.5-1 \mathrm{mg} \cdot \mathrm{L}^{-1} 2 \mathrm{PP}$. Because of the low concentration needed and lack of subsequent problems with rooting, benzyladenine was chosen for the further experiments in 
ninebark as the most cost-effective of all the cytokinins tested. Earlier it proved suitable for the cultivar "DIABLE" OR "Mindia" (Ilczuk et al. 2013).

Low concentration of NAA stimulated the cytokinininduced proliferation in ninebark. Similarly, a synergetic influence of BA and NAA was noticeable in Ruta graveolens when the combinations of the most favorable concentration of BA with variant concentrations of NAA were tested: supplementation of NAA resulted in a better shoot proliferation rate and the best regeneration (Faisal et al. 2018). In Juglans regia the best proliferation results were obtained with $1 \mathrm{mg} \cdot \mathrm{L}^{-1}$ of BA plus $0.01 \mathrm{mg} \cdot \mathrm{L}^{-1}$ of IBA (Kepenek and Kolagasi 2016). During multiplication phase the auxin IAA or IBA was always present in culture media used for seven ornamental plants differing in sensitivity towards cytokinins BA or Kin (Vardja and Vardja 2001).

In most cases, shoot elongation is enhanced by GA (Gupta and Chakrabarty 2013), but not in the ninebark tested here. GA did not affect shoot growth but shoot proliferation, and the highest shoot number per explant were obtained with $1 \mathrm{mg}$. $\mathrm{L}^{-1} \mathrm{GA}_{3}$. Similar effect was reported for five raspberry cultivars (Zawadzka and Orlikowska 2006), apricot (Koubouris and Vasilakakis 2006), and lavender (Machado et al. 2011).

With time spent in vitro, senescence symptoms become frequent, mutations appear, and epigenetic changes may accumulate, reducing the multiplication ratio, lowering plant vigor, or inducing changes in plant morphology (Huang et al. 2012). Ninebark cultures and their regeneration ability were observed during 20 subcultures, and no substantial differences in the percentage of explants regeneration on the same medium were noted. The lowest numbers of shoots per explants and the shortest shoots were in the first subculture. Similar observation was made by Javed et al. (2013) on Acacia ehrenbergiana, and it was explained by the effect of the oxidative stress after mechanical wounding of plant material during culture establishment. Apart from this, at the beginning of culture, the explants use part of their energy to adapt to new conditions in vitro instead of spending it on growth. Similarly, in Rubus pubescens, the regeneration parameters were the lowest in the first subculture; in the second and third passage, they improved and remained on the same level during successive subcultures (Debnath 2004). Another tendency was reported by Remphrey et al. (1993) who studied the effect of the long-term culture on regeneration in Potentilla fruticosa: regeneration potential peaked in the second passage and declined during successive subcultures until the tenth passage. Also, in rootstocks of fruit trees, the regeneration ability declined during the long-term culture including 10 subcultures (Vujović et al. 2012). Sometimes it is recommended to reduce by half the BA content of the multiplication medium after the 5 th or 6th subculture or to transfer a culture onto media of lesser salt content from time to time (Vardja and Vardja 2001). In ninebark "Dart's Gold," the highest shoot numbers per explant were produced on the same medium between passages 10 and 17 , and there was no relationship between the culture age and the shoot length even after 20 successive subcultures, i.e., for over 3 years.

In the rooting phase of micropropagation, the culture medium is designed to produce well-developed root systems in cuttings. Not only the mineral composition of the medium is decisive, but also, the nutrient concentration is important. Excessive amounts of salts may limit root development; hence, media with lowered salt concentrations are often used. According to Hong (1996), explants of Rosa chinensis rooted better on one half MS than on 1x MS. Similar observations were made by Kikowska et al. (2014) on Eryngium maritimum, by Fadel et al. (2010) on Mentha spicata, and by Bidarigh and Azarpour (2013) on Camellia sinensis. In this study, there was no difference between one half and 1x MS so a reduction of the MS concentration reduces the cost of the process without affecting the outcome.

Auxin is the main hormone controlling rhizogenesis. Exogenous auxin in a culture medium may affect enzyme activities in tissues (IAA oxidase and peroxidase) and phenolic compounds contents, thus creating a hormone balance suitable for root initiation (Qaddoury and Amssa 2004). Auxin activates root primordia or stimulates their mitotic activity (De Klerk et al. 1999). Among various auxins used to stimulate rooting IBA is the most commonly used, IAA and NAA are considered as less suitable (Hartmann et al. 2011) but much appears to depend on the species involved. Ahn et al. (2007) obtained comparable results with IBA and NAA in Ricinus communis; however, plants rooted in the presence of IBA showed a higher rate of establishment in the soil (93.5 vs $39.5 \%$ ) and a better growth. In Prunus armeniaca (Koubouris and Vasilakakis 2006) and P. dulcics (Tereso et al. 2008) rooting was better with IBA, IAA, or IBA than NAA simillary as in Acacia chundra (Rout et al. 2008). In an apple rootstock "Jork 9" IAA and IBA gave comparable results when used at optimal concentrations. However, IAA was effective in a concentration range between $1.8 \mathrm{mg} \cdot \mathrm{L}^{-1}$ and $17.5 \mathrm{mg} \cdot \mathrm{L}^{-1}(10-100 \mu \mathrm{M}$ IAA), while IBA had only one optimal value, i.e., $\mathrm{mg} \cdot \mathrm{L}^{-1}(10 \mu \mathrm{M})$ (De Klerk et al. 1999). In this study, IBA produced better rooting than NAA, but as in some other studies (De Klerk et al. 1999), the range of effective concentrations was narrow.

Acclimation is the last phase of micropropagation when plants produced in vitro are gradually adjusted to external conditions. Various conditions in vitro may result in development of plants with altered morphology, anatomy, and physiology. A transfer to external environment may result in damage and physiological disorders. Usually, stomata of in vitrogenerated plants do not function normally, so a reduction of the transpiration rate is crucial for plant hardening. Antitranspirants such as ABA are generally used to hasten acclimation as they close stomata and reduce water losses 
(Pospiśílová et al. 1999; Rai et al. 2011). ABA can be delivered in a different ways, via spray or a media supplement. As a media supplement, it increased the survival rate in Tagetes erecta and increased leaf area (Aguilar et al. 2000). Mulberry plants treated with ABA during the last subculture acclimatized in a higher percentage and had better growth parameters than untreated plants (Huh et al. 2017). In this study, cuttings sprayed with ABA acclimatized in a higher percentage than those sprayed with water. After 2 months of acclimation, they were also taller. Another important factor in acclimation is light. Leaves developed in vitro are usually unable to produce sufficient amounts of metabolites necessary for normal development. Increased light intensity during acclimation hastens growth of new leaves which are fully autotrophic (Donnelly and Vidaver 1984). Here, supplementary lighting during acclimation significantly increased plant height and internode number.

Recently, a particular emphasis is placed on ex vitro rooting of microcuttings as it saves time, costs, and labor of plant production (Shekhawat and Manokari 2015). Not only the production cycle can be shortened, but more plants survive the transfer from in vitro to ex vitro conditions, and the acclimation to greenhouse conditions proceeds simultaneously with the ex vitro rooting (Phulwaria and Shekhawat 2013; Shekhawat and Manokari 2015; Ravindran et al. 2016; Singh and Agarwal 2016). The percentage of plants of Vaccinium corymbosum L. "Berkeley" and V. angustifolium $\times V$. corymbosum "Northsky" rooted and acclimatized ex vitro was nearly $100 \%$ (Isutsa et al. 1994). In the difficult-to root magnolia, the percentage of rooted cuttings and the mean root number were higher under the ex vitro conditions relative to in vitro (Parris et al. 2012). Ex vitro rooting of ninebark microcuttings was successful in our trials with $80 \%$ success rate after soaking them in a water IBA solution. As ABA increases plant tolerance to adverse conditions, it is usually used to improve acclimation of the ex vitro-rooted microcuttings. Twice as many cuttings of Jatropha curcas rooted ex vitro after a pretreatment with ABA as compared with untreated cuttings (Singh et al. 2014). However, in this study no effect of sprayed ABA was observed.

\section{Conclusions}

Overall, this study offers an effective and efficient protocol for micropropagation of ninebark. Reduction in media concentrations, adjustments in growth regulator combinations, and direct rooting of cuttings during acclimation process reduce the overall cost of the process and make it much more efficient. Unfortunately, it appears quite likely that individual steps and the component compositions may have to be tailored to individual cultivars. Only such protocols may help to satisfy the growing demand for this ornamental shrub. The following conclusions might be helpful in micropropagation of ninebark "Dart's Gold.'

1. 1x MS basal medium, $\mathrm{pH} 5.8$, supplemented with $2 \%$ sorbitol produced the best regeneration rates in ninebark "Dart's Gold."

2. The type and concentration of cytokinin in the culture medium significantly affected regeneration. Benzyladenine at $1 \mathrm{mg} \cdot \mathrm{L}^{-1}$ proved the most costeffective cytokinin, while the presence of gibberellic acid in the culture medium containing NAA and BA further increased proliferation.

3. There was no effect of the culture age (up to 20 subcultures) on the percentage of regenerating explants.

4. One half MS macronutrient concentration was sufficient for rhizogenesis which was better stimulated by the auxin IBA than NAA.

5. Spraying the in vitro rooted cuttings with ABA favored plant acclimation to the ex vitro conditions.

6. The ex vitro rooting was successful in reducing the production time by a third.

Open Access This article is licensed under a Creative Commons Attribution 4.0 International License, which permits use, sharing, adaptation, distribution and reproduction in any medium or format, as long as you give appropriate credit to the original author(s) and the source, provide a link to the Creative Commons licence, and indicate if changes were made. The images or other third party material in this article are included in the article's Creative Commons licence, unless indicated otherwise in a credit line to the material. If material is not included in the article's Creative Commons licence and your intended use is not permitted by statutory regulation or exceeds the permitted use, you will need to obtain permission directly from the copyright holder. To view a copy of this licence, visit http://creativecommons.org/licenses/by/4.0/.

\section{References}

Aguilar ML, Espadas FL, Coello J et al (2000) The role of abscisic acid in controlling leaf water loss, survival and growth of micropropagated Tagetes erecta plants when transferred directly to the field. J Exp Bot 51:1861-1866

Ahmad T, Abbasi NA, Hafiz IA, Ali A (2007) Comparison of sucrose and sorbitol as main carbon energy sources in micropropagation of peach rootstock GF-677. Pak J Bot 39(4):1269-1275

Ahn Y, Wang L, McKeon TA, Chen GQ (2007) High-frequency plant regeneration through adventitious shoot formation in castor (Ricinus communis L.). In Vitro Cell Dev- Plant 43:9-15

Anderson WC (1980) Tissue culture propagation of red and black raspberries, Rubus idaeus and R. occidentalis. Acta Hortic 13-20. https://doi.org/10.17660/ActaHortic.1980.112.1

Bidarigh S, Azarpour E (2013) Evaluation of the effect of MS medium levels on rooting in micro cuttings of tea (Camellia sinensis L.) under in vitro culture condition. ARPN J Agric Biol Sci 8:24-28

Cui Y, Deng Y, Zheng K et al (2019) An efficient micropropagation protocol for an endangered ornamental tree species (Magnolia sirindhorniae Noot. \& Chalermglin) and assessment of genetic 
uniformity through DNA markers. Sci Rep 9:1-10. https://doi.org/ 10.1038/s41598-019-46050-w

Davies PJ (2010) The plant hormones: their nature, occurrence, and functions. In: Plant Hormones. Biosynthesis, Signal Transduction, Action! Springer, Ithaca, pp 1-15

De Klerk GJ, van der Kriken W, De Jong JC (1999) The formation of adventitious roots: new concepts, new possibilities. In Vitro Cell Dev- Plant 35:189-199

De Neto VBP, Otoni WC (2003) Carbon sources and their osmotic potential in plant tissue culture: does it matter? Sci Hortic 97:193-202

Debnath SC (2004) Clonal propagation of dwarf raspberry (Rubus pubescens Raf.) through in vitro axillary shoot proliferation. Plant Growth Regul 43:179-186

Declerck V, Korban SS (1996) Influence of growth regulators and carbon sources on callus induction, growth and morphogenesis from leaf tissues of peach (Prunus persica L. Batsch). J Hortic Sci 71:49-55. https://oi.org/10.1080/14620316.1996.11515381

Dimitrova N, Nacheva L, Berova M (2016) Effect of meta-topolin on the shoot multiplication of pear rootstock OHF-333 (Pyrus communis L.). Acta Sci Pol Hortorum Cultus 15:43-53

Donnelly DJ, Vidaver WE (1984) Pigment content and gas exchange of red raspberry in vitro and ex vitro. J Am Soc Hortic Sci 109:177-181

Ďurkovič J (2008) Micropropagation of mature Cornus mas 'Macrocarpa'. Trees 22:597-602

Ďurkovič J, Bukovská J (2009) Adventitious rooting performance in micropropagated Cornus mas. Biol Plant 53:715-718

Fadel D, Kintzios S, Economou AS, Moschopoulou G, Constantinidou HIA (2010) Effect of different strength of medium on organogenesis, phenolic accumulation and antioxidant activity of spearmint (Mentha spicata L.). The Open Horticulture Journal 3:31-35

Faisal M, Ahmad N, Anis M, Alatar AA, QahtanAA (2018) Auxin and cytokinin synergism in in vitro producing genetically stable plants of Ruta graveolens using shoot tip meristems. Saudi J Biol Sci 25:273277

Feng CM, Rongda Q, Zhou LL, Xie DY, Xiang QJ (2009) Shoot regeneration of dwarf dogwood (Cornus canadensis L.) and morphological characterization of the regenerated plants. Plant Cell Tiss Cult 97:27-37. https://doi.org/10.1007/s11240-009-9495-0

Gallo CM, Radmann EB, Ritterbusch CW et al (2017) The effect of the culture media components by in vitro multiplication ' $\mathrm{Mr}$. S 2/5' rootstock. Ciência Agrícola Rio Largo 15(1):9-16. https://doi.org/ 10.28998/rca.v15i1.2607

Garg P, Malik CP (2012) Multiple shoot formation and efficient root induction in Cissus quadrangularis. Int J Pharm Clin Res 4(1):4-10

Gentile A, Gutiérrez MJ, Martinez J et al (2014) Effect of meta-Topolin on micropropagation and adventitious shoot regeneration in Prunus rootstocks. Plant Cell Tiss Cult 118:373-381. https://doi.org/10. 1007/s11240-014-0489-1

George EF, Hall MA, De Klerk GJ (2007) Plant propagation by tissue culture. Springer Netherlands, Dordrecht

Gupta R, Chakrabarty SK (2013) Gibberellic acid in plant - still a mystery unresolved. Plant Signal Behav 8(9):1-5. https://doi.org/10.4161/ psb. 25504

Gürel S, Gülșen Y (1998) The effects of different sucrose, agar and $\mathrm{pH}$ levels on in vitro shoot production of almond (Amygdalus communis L.). Turk J Bot 22:363-373

Haque MS, Wada T, Hattori K (2003) Effects of sucrose, mannitol and $\mathrm{KH} 2 \mathrm{PO} 4$ on root tip derived shoots and subsequent bulblet formation in garlic. J Asian Plant Sci 2(12):903-908

Hartmann HT, Kester DE, Davies FT, Geneve R (2011) Propagation of ornamental trees, shrubs, and woody vines. In: Hartmann and Kester's Plant Propagation: Principles and Practices, 8th edn. Prentice Hall, Upper Saddle River, pp 774-839

Hazarika BN (2006) Morpho-physiological disorders in in vitro culture of plants. Sci Hortic (Amsterdam) 108:105-120. https://doi.org/10. 1016/j.scienta.2006.01.038
Hong Z (1996) Tissue culture of Rosa chinensis var. Floribunda. J Northeast For Univ 7:41-45

Huang H, Han SS, Wang Y, Zhang XZ, Han ZH (2012) Variations in leaf morphology and DNA methylation following in vitro culture of Malus xiaojinensis. Plant Cell Tiss Org 111:153-161

Huh YS, Lee JK, Nam SY (2017) Improvement of ex vitro acclimatization of mulberry plantlets by supplement of abscisic acid to the last subculture medium. J Plant Biotechnol 44:431-437. https://doi.org/ 10.5010/JPB.2017.44.4.431

Hussain A, Ahmed I, Nazir H, Ullah I (2012) Plant tissue culture: current status and opportunities. In: Leva A, Rinaldi LMR (eds) Recent advances in plant in vitro culture. InTech, Rijeka, pp 1-28

Ilczuk A, Jagiełło-Kubiec K, Jacygrad E (2013) The effect of carbon source in culture medium on micropropagation of common ninebark (Physocarpus opulifolius (L.) maxim.) "Diable D'or". Acta Sci Pol Hortorum Cultus 12:23-33

Isutsa DK, Pritts MP, Mudge KW (1994) Rapid propagation of blueberry plants using ex vitro rooting and controlled acclimatization of micropropagules. HortScience 29(10):1124-1126

Javed SB, Anis M, Khan PR, Aref IM (2013) In vitro regeneration and multiplication for mass propagation of Acacia ehrenbergiana Hayne: a potential reclaiment of denude arid lands. Agrofor Syst 87:621-629. https://doi.org/10.1007/s10457-012-9583-8

Kassim NE, Abou Rayya SM, Ali EAM (2010) Effect of explant types and different basal nutrient media on in vitro growth of bitter almond cuttings during establishment and proliferation stages. J Am Sci 6(9):340-343

Kaveriappa KM, Phillips LM, Trigiano RN (1997) Micropropagation of flowering dogwood (Cornus florida) from seedlings. Plant Cell Rep 16:485-489. https://doi.org/10.1007/BF01092771

Kepenek K, Kolagasi Z (2016) Micropropagation of Walnut (Juglans regia L.). Acta Phys Pol A 130(1):150-156. https://doi.org/10. 12693/APhysPolA.130.150

Kikowska M, Thiem B, Sliwinska E et al (2014) The effect of nutritional factors and plant growth regulators on micropropagation and production of phenolic acids and saponins from plantlets and adventitious root cultures of Eryngium maritimum L. J Plant Growth Regul 33:809-819. https://doi.org/10.1007/s00344-014-9428-y

Koszeghi S, Bereczki C, Balog A, Benedek K (2014) Comparing the effects of benzyladenine and meta-Topolin on sweet basil (Ocimum basilicum) micropropagation. Not Sci Biol 6:422-427. https://doi.org/10.15835/nsb649464

Koubouris G, Vasilakakis M (2006) Improvement of in vitro propagation of apricot cultivar 'Bebecou'. Plant Cell Tissue Organ Cult 85:173180. https://doi.org/10.1007/s11240-005-9066-y

Kozai T (1991) Micropropagation under photoautotrophic conditions. In: Debergh PC, Zimmerman RH (eds) Micropropagation. Springer, Dordrecht, pp 447-469. https://doi.org/10.1007/978-94-009-2075026

Kumar A, Aggarwal D, Gupta P, Reddy MS (2010) Factors affecting in vitro propagation and field establishment of Chlorophytum borivilianum. Biol Plant 54:601-606. https://doi.org/10.1007/ s10535-010-0109-9

Lisowska K, Wysokinska H (2000) In vitro propagation of Catalpa ovata G. Don. Plant Cell Tissue Organ Cult 60:171-176. https://doi.org/ 10.1023/A: 1006461520438

Lloyd G, McCown B (1980) Commercially-feasible micropropagation of mountain laurel Kalmia latifolia by use of shoot-tip culture. Comb Proc, Int Plant Propagators' Soc 30:421-427

Machado MP, da Silva ALL, Biasi LA (2011) Effect of plant growth regulators on in vitro regeneration of Lavandula dentata $\mathrm{L}$. shoot tips. J Biotec and Biodivers 2(3):28-31

Matt A, Jehle JA (2005) In vitro plant regeneration from leaves and internode sections of sweet cherry cultivars (Prunus avium L.). Plant Cell Rep 24(8):468-476. https://doi.org/10.1007/s00299. 005-0964-6 
Mercier H, Kerbauy B, Sotta B, Mignia E (1997) Effects of NO3-, NH4+ and urea nutrition on endogenous levels of IAA and four cytokinins in two epiphytic bromeliads. Plant Cell Environ 20:387-392. https:// doi.org/10.1046/j.1365-3040.1997.d01-72.x

Micheli M, Standardi A, El Behi AW et al (2010) In vitro proliferation of olive ('Dolce Agogia' and 'Moraiolo'): effect of different cytokinins. Acta Hortic 884:587-590. https://doi.org/10.17660/ ActaHortic.2010.884.76

Misalova A, Durković J, Mamonova M et al (2009) Changes in leaf organisation, photosynthetic performance and wood formation during ex vitro acclimatisation of black mulberry (Morus nigra L.). Plant Biol 11:686-693. https://doi.org/10.1111/j.1438-8677.2008. 00166.x

Moing A, Carbonne F, Rashad MH, Jean-Pierre G (1992) Carbon fluxes in mature peach leaves. Plant Physiol 100:1878-1884

Murai Y, Harada H, Yamashita H (1997) In vitro propagation of apricot (Prunus armeniaca L.) cv. 'Bakuoh junkyou'. J Jpn Soc Hortic Sci 66:475-480

Murashige T, Skoog F (1962) A revised medium for rapid growth and bio assays with Tobacco tissue cultures. Physiol Plant 15:473-497

Naik D, Vartak V, Bhargava S (2003) Provenance- and subculturedependent variation during micropropagation of Gmelina arborea. Plant Cell Tiss Org 73:189-195. https://doi.org/10.1023/A: 1022886621852

Nitsch JP, Nitsch C (1969) Haploid plants from pollen grains. Science 163:85-87. https://doi.org/10.1126/science.163.3862.85

Norton ME, Norton CR (1986) Change in shoot proliferation with repeated in vitro subculture of shoots of woody species of Rosaceae. Plant Cell Tiss Org 5:187-197. https://doi.org/10.1007/BF00040129

Nowakowska K, Pacholczak A, Tepper W (2019) The effect of selected growth regulators and culture media on regeneration of Daphne mezereum L. 'Alba.'. Rend Lincei 30:197-205. https://doi.org/10. 1007/s12210-019-00777-w

Pacholczak A (2015) The effect of the auxin application methods on rooting of Physocarpus opulifolius Maxim, cuttings. Propag Ornam Plants 15(4):147-153

Pacholczak A, Szydło W (2008) Effect of ammonium zinc acetate on rooting of stem cuttings in Phycocarpus opulifolius. Ann Warsaw Univ of Life Sci - SGGW, Horticult Landsc Architect 29:59-64

Parris JK, Touchel DH, Ranney TG, Adelberg J (2012) Basal salt composition, cytokinins, and phenolic binding agents influence in vitro growth and ex vitro establishment of Magnolia 'Ann.' HortScience 47:1625-1629. https://doi.org/10.21273/HORTSCI.47.11.1625

Pawłowska B (2011) The effect of BA and GA3 on the shoot multiplication of in vitro cultures of Polish wild roses. Folia Hortic 23:145149. https://doi.org/10.2478/v10245-011-0022-5

Perveen S, Varshney A, Anis M, Aref IM (2011) Influence of cytokinins, basal media and $\mathrm{pH}$ on adventitious shoot regeneration from excised root cultures of Albizia lebbeck. J For Res 22:47-52. https://doi.org/ 10.1007/s11676-011-0124-5

Phulwaria M, Shekhawat NS (2013) An efficient in vitro shoot regeneration from immature inflorescence and ex vitro rooting of Arnebia hispidissima (Lehm). DC. - A red dye (Alkannin) yielding plant. Physiol Mol Biol Plants 19(3):435-441. https://doi.org/10.1007/ s12298-013-0171-9

Pierik RLM (1997) In vitro culture of higher plants. Springer, Berlin, p 348. https://doi.org/10.1007/978-94-011-5750-6

Podwyszyńska M, Wegrzynowicz-Lesiak E, Doležal K et al (2012) New cytokinin-meta-methoxytopolins in micropropagation of Cotinus. Propag Ornam Plants 12:220-228

Popek R, Przybysz A, Gawrońska H, Klamkowski K, Gawroński SW (2018) Impact of particulate matter accumulation on the photosynthetic apparatus of roadside woody plants growing in the urban conditions. Ecotoxicol Environ Saf Pub 163:56-62. https://doi.org/ 10.1016/j.ecoenv.2018.07.051
Pospisilova J, Ticha I, Kadlecek P et al (1999) Acclimatization of micropropagated plants to ex vitro conditions. Biol Plant 42:481497. https://doi.org/10.1023/A:1002688208758

Qaddoury A, Amssa M (2004) Effect of exogenous indole butyric acid on root formation and peroxidase and indole-3-acetic acid oxidase activities and phenolic contents in date palm offshoots. Bot Bull Acad Sin 45:127-131

Quoirin M, Lepoivre P (1977) Improved media for in vitro culture of Prunus sp. Acta Hortic 78:437-442. https://doi.org/10.17660/ ActaHortic.1977.78.54

Radha RK, Varghese AM, Seeni S (2013) Conservation through in vitro propagation and restoration of Mahonia leschenaultii, an endemic tree of the Western Ghats. Sci Asia 39:219-229. https://doi.org/10. 2306/scienceasia1513-1874.2013.39.219

Rai MK, Shekhawat NS, Harish et al (2011) The role of abscisic acid in plant tissue culture: A review of recent progress. Plant Cell Tissue Organ Cult 106:179-190. https://doi.org/10.1007/s11240-0119923-9

Ravindran CP, Manokari M, Shekhawat MS (2016) In vitro propagation through ex vitro rooting of a medicinal spice Piper longum Linn. World Sci News 37:12-24

Rédei GP (1979) 'Fructose Effect' in higher plants. Ann Bot 38(2):287_ 297

Remphrey WR, Palmer CE, Blouw MJ (1993) In vitro branching in relation to repeated subculture in two cultivars of Potentilla fruticosa. Plant Cell Tiss Org 32:235-240. https://doi.org/10.1007/ BF00029848

Rout GR, Senapati SK, Aparajeta S (2008) Micropropagation of Acacia chundra (Roxb.) DC. Hort Sci (Prague) 35(1):22-26

Schenk RU, Hildebrandt AC (1972) Medium and techniques for induction and growth of monocotyledonous and dicotyledonous plant cell cultures. Can J Bot 50:199-204. https://doi.org/10.1139/b72-026

Shekhawat MS, Manokari M (2015) Efficient in vitro propagation by ex vitro rooting methods of Artemisia absinthium L., an ethnobotanically important plant. Chin J Biol 2015:1-8. https:// doi.org/10.1155/2015/273405

Shekhawat MS, Manokari M (2016) In vitro propagation, micromorphological studies and ex vitro rooting of cannon ball tree (Couroupia guaianensis Aubl.): a multipurpose threatened species. Physiol Mol Biol Plants 22:131-142. https://doi.org/10.1007/s12298-015-0335$\mathrm{x}$

Singh A, Agarwal PK (2016) Enhanced micropropagation protocol of ex vitro rooting of a commercially important crop plant Simmondsia chinensis (Link) Schneider. J For Sci 62(3):107-115. https://doi.org/ 10.17221/80/2015-JFS

Singh A, Jani K, Sagervanshi A, Agrawal PK (2014) High-frequency regeneration by abscisic acid (ABA) from petiole callus of Jatropha curcas. In Vitro Cell Dev Biol-Plant 50:638-645. https://doi.org/10.1007/s11627-014-9628-y

Sivanesan I, Song JY, Hwang SJ, Jeong BR (2011) Micropropagation of Cotoneaster wilsonii Nakai - a rare endemic ornamental plant. Plant Cell Tiss Org 105:55-63. https://doi.org/10.1007/s11240-0109841-2

Stoop JMH, Pharr DM (1993) Effect of different carbon sources on relative growth rate, internal carbohydrates, and mannitol 1oxidoreductase activity in celery suspension cultures. Plant Physiol 103:1001-1008

Tereso S, Miguel CM, Mascarenhas M, Roque A et al (2008) Improved in vitro rooting of Prunus dulcis Mill. cultivars. Biol Plant 52(3): 437-444

Thorpe T, Stasolla C, Yeung EC et al (2008) The components of plant tissue culture media II: organic additions, osmotic and $\mathrm{pH}$ effects, and support systems. In: George EF, Hall MA, De Klerk GJ (eds) (red.). Plant propagation by tissue culture, 3rd ed volume 1 , the background. Springer, Dordrecht, pp 115-173 
Vardja R, Vardja T (2001) The effect of cytokinin type and concentration and the number of subcultures on the multiplication rate of some decorative plants. Proc Estonian Acad Sci Biol Ecol 50(1):22-32

Vujović T, Ruzić D, Cerović R (2012) In vitro shoot multiplication as influenced by repeated subculturing of shoots of contemporary fruit rootstocks. Hort Sci (Prague) 39(3):101-107

Werbrouck SPO, Strnad M, Van Onckelen HA, Debergh PC (1996) Meta-topolin, an alternative to benzyladenine in tissue culture? Physiol Plant 98:291-297

Wójcik AR, Laudański Z (1989) Planowanie i wnioskowanie statystyczne w doświadczalnictwie. [Planning and statistical evaluation in experiments]. Wydawnictwo Naukowe PWN, Warszawa, $p$ 318

Wojtania A (2010) Effect of Meta-topolin on in vitro propagation of Pelargonium $\times$ hortorum and Pelargonium $\times$ hederaefolium cultivars. Acta Soc Bot Pol 79(2):101-106

Yan H, Liang C, Yang L, Li Y (2010) In vitro and ex vitro rooting of Siratia grosvenorii, a traditional medicinal plant. Acta Physiol Plant $32: 115-120$
Yaseen M, Ahmad T, Sablok G et al (2013) Review: role of carbon sources for in vitro plant growth and development. Mol Biol Rep 40:2837-2849. https://doi.org/10.1007/s11033-012-2299-z

Yaseen M, Ahmed T, Abbasi NA, Hafiz IA (2009) In vitro shoot proliferation competence of apple rootstocks M.9 and M.26 on different carbon sources. Pak J Bot 41:1781-1795

Yuji I, Yoshihiro W, Yoko S, et al (1993) Establishment of tissue and cell culture system of tropical Acacia species for acid-resistant clones: Proceedings of International Workshop BIO-REFOR, Yogyakarta, pp. $149-153$

Zawadzka M, Orlikowska T (2006) Factors modifying regeneration in vitro of adventitious shoots in five red raspberry cultivars. J Fruit and Ornam Plant Res 14:105-115

Ziv M (1995) In: Aitken-Christie J, Kozai T, Smith ML (eds) In vitro acclimatization. Automation and environmental control in plant tissue culture. Kluwer Academic Publishers, Dordrecht, pp 493-516 